\title{
Managing Inventories In Global Sourcing Contexts: A Contingency Perspective
}

\author{
PLEASE CITE AS: Golini, R., Kalchschmidt, M., 2015. Managing inventories in global \\ sourcing contexts: A contingency perspective. International Journal of Production \\ Economics 165, 64-78.
}

doi:10.1016/j.ijpe.2015.03.022

\section{Highlights}

- We replicate Golini and Kalchschmidt (2011) with updated data

- We confirm that global sourcing increases inventory level

- As a consequence, global sourcing companies invest in supply chain management

- The effect of investments changes according to certain contingencies

- For instance, larger or upstream companies have higher pay-off

\begin{abstract}
One of the key problems of global supply chains is how to keep inventories low. Even if there is evidence that supply chain management tools can help in this direction, an underinvestigated point is how companies in different contexts experience the effects of global sourcing and the outcomes on their material inventory level. Based on a model proposed by Golini and Kalchschmidt (2011), the aim of this paper is to verify whether different companies - in terms of contingency variables - experience different impacts of globalisation and supply chain management on the material inventory level. In this work, several contingency variables were selected from the literature i.e., company size, product complexity, type of production, type of purchases, number of suppliers and number of suppliers per item. The results show that when considering groups of companies characterised by different contingent variables, the relationship between globalisation, supply chain investments and material inventory levels is valid only for some groups, whereas it loses its significance for others.
\end{abstract}

Keywords: global sourcing; contingency analysis; supply chain management; IMSS

\section{Introduction}

Driven by market standardisation, openness of borders and improvements in transportation and communication technologies, globalisation has become an increasingly relevant phenomenon in the last decades. To exploit the advantages of globalisation (e.g., low cost labour, resources, access to new markets) and to respond to growing competition, companies have increasingly expanded their supply chains beyond national borders (Hülsmann et al., 2008; Kotabe and Murray, 2004; Skjott-Larsen and Schary, 2007). This expansion has made it critical to understand how companies behave when they purchase globally. Global sourcing 
can lead to higher costs for buyers due to logistics costs, transportation and higher inventory levels (Tan, 2001). Supply chain risks can also become more relevant, thus reducing the willingness of companies to move away from local suppliers (Stratton \& Warburton, 2006). Cultural distance can also be a limitation in some cases, leading to higher transaction costs (Hartmann, Trautmann, \& Jahns, 2008). These are some of the reasons that global sourcing is still not broadly adopted (Cagliano et al., 2008; Trent and Monczka, 2003) and its effects on performance are not completely straightforward (Kotabe and Omura, 1989; Steinle and Schiele, 2008).

One of the problem companies face when dealing with global sourcing is how to keep inventories low (Narasimhan and Mahapatra, 2004). As a matter of fact, longer distances increase the consignment lead times and variability; thus, companies might have to keep higher material inventories to avoid stock-outs and production stops (Bygballe et al., 2011; Han et al., 2008; Harris, 1913; Stratton and Warburton, 2006).

To limit this problem, companies can invest in supply chain management. Generally speaking, supply chain management implies collaboration with suppliers to make the supply chain more efficient and/or responsive (Fisher, 2003; Sheth and Sharma, 1997). One of the benefits is usually reduced or better allocated inventories, as happens, for example with justin-time techniques (e.g.Adair-Heeley, 1988). Different types of supply chain management investments are usually adopted in global sourcing contexts, such as information sharing and other coordination systems (Nassimbeni and Sartor, 2007; Trent and Monczka, 2003).

In this literature stream, Golini and Kalchschmidt (2011) provided evidence that, in the manufacturing industry, it is possible to almost fully moderate the negative impact of global sourcing on material inventory levels through supply chain management investments (SCMI). In their work, they find that global sourcing increases material inventory levels; however, companies adopting global sourcing have a higher adoption of SCMI, which, in turn, reduces material inventory levels. Ultimately, the total effect of global sourcing on material inventory levels is very low.

\section{TAKE IN FIGURE 1}

The proposed model was tested using survey data collected in 2005 from almost 500 companies operating in the assembly industry in different countries all over the world. However, Golini and Kalchschmidt (2011) did not consider the specific characteristics of the context in which companies operate. We thus aim to extend the Golini and Kalchschmidt (2011) model by including contingency variables.

As a matter of fact, understanding under which conditions companies will obtain higher benefits by increasing collaborations with global suppliers is important for different reasons. Among these, implementing SCMI usually represents a significant cost, therefore, it is important to invest only in those situations in which there is higher need and these investments can be more effective.

We therefore aim to verify whether the Golini and Kalchschmidt (2011) model holds for different groups of companies, which are defined on the basis of a set of literature-based contingencies. In particular, the identified contingent variables are: company size, product complexity, type of production, type of purchases and number of suppliers. Because these variables cannot be traced back to a unique grand theory, we consider this paper to be an exploratory analysis in line with other contributions performing similar contingency analyses 
(e.g. Shah and Ward, 2003). Moreover, we will also verify whether the model proposed by Golini and Kalchschmidt (2011), based on data collected in 2005, still holds using data collected in 2009. This is useful to show whether it is still possible to reduce the impact of global sourcing on inventories through SCMI.

The remainder of the paper is structured as follows. In the next section, the concept of global sourcing is described, the literature on the relationship between global sourcing and inventory levels is reported and the most relevant contingent variables and their effects are presented. Next, the research method and the empirical analysis are described. Subsequently, a discussion of the results is provided, and, finally, we draw conclusions and suggest potential avenues for future research.

\section{Literature Review and Research Propositions}

\subsection{Global Sourcing, Inventories and Supply Chain Management}

Global sourcing can provide several advantages to companies, including lower procurement prices, new technologies, knowledge or higher-quality products (Bozarth et al., 1998; Frear et al., 1992; Monczka and Trent, 1991; Nassimbeni and Sartor, 2007). However, fiscal aspects (e.g., taxation or currency), trading agreements between countries, access to new markets, shorter product development processes and product life cycles, or even company image, can also be motivating factors (Frear et al., 1992; Nassimbeni and Sartor, 2007).

However, it is not always easy to exploit such benefits due to the difficulties that arise when sourcing globally (Dornier et al., 2008; Handfield, 1994; MacCarthy and Atthirawong, 2003). Geographical distance causes longer and more variable lead times because multiple means of transportation are used. Moreover, for the sake of efficiency (e.g., to fill containers), batches ordered from distant suppliers have to be larger than those from domestic suppliers. Furthermore, global sourcing carries specific issues related to lower knowledge of the suppliers and possible infrastructural deficiencies in developing countries (Meixell and Gargeya, 2005). Finally, there can be major risks of supply chain disruptions, political instability in sourcing countries or exchange price fluctuations that can undermine global sourcing profitability (Carter and Vickery, 1989; Dornier et al., 2008).

Therefore, in a global sourcing setting, companies typically use inventories as a shield for supply variability and disruption (Hendricks and Singhal, 2005; Stratton and Warburton, 2006). This, however, can be particularly costly and difficult to sustain, especially in periods when companies face financial constraints (Guariglia, 1999), such as today's. Alternatives to overcome the problem include sharing inventory risks with suppliers (Lai et al., 2009) or more generally applying SCMI to reduce inventories (Krause et al., 1998; Tan, 2001; Watts and Hahn, 1993).

As previously mentioned, Golini and Kalchschmidt (2011) provide an effective synthesis of the problem. The results of this paper provide evidence for a relevant negative impact of global sourcing on inventory performance that can be partially reduced through the adoption of proper SCMI that act as mediator variables. As a matter of fact, globally sourcing companies that have implemented SCMI have inventory levels that are comparable to those of locally sourcing companies. However, globally sourcing companies that have implemented few SCMI efforts have the worst inventory performance of the entire sample.

The model by Golini and Kalchschmidt (2011) was built using 2005 data, but, despite the rapid changes at the global level, we expect the model to hold also using data collected in 2009. In fact, recent literature supports the finding that global sourcing causes higher 
inventory levels (Holweg et al., 2011) and SCMI helps keep inventories low (Fawcett et al., 2008). Therefore, our first research proposition is:

RP1. The model by Golini and Kalchschmidt (2011) holds using 2009 data in that the sign of the relationships among global sourcing, inventories and SCMI remains the same.

The same model by Golini and Kalchschmidt (2011) included different types of SCMI.

Entering into the detail, the practices advocated to be more beneficial for inventory reduction are those related to supply chain coordination. These investments can be grouped into two categories: information sharing and system coupling (e.g., Cagliano et al., 2003; Frohlich and Westbrook, 2001).

Information sharing pertains to exchanging information about inventory levels, production plans and forecasts with suppliers. This practice requires the standardisation of the information technology infrastructure; thus, its adoption has been significantly fostered by the diffusion of Internet-based tools (e.g., Caniato et al., 2009). System coupling is deployed with suppliers' processes, such as just-in-time (JIT), collaborative planning forecasting and replenishment or vendor-managed inventory, with the objective of achieving faster product flows with fewer inventories (e.g. Power, 2005).

Investments, both in information sharing and system coupling, aim to better coordinate the material flows among suppliers and customers with beneficial effects on inventories also in global supply chain contexts (Babbar and Prasad, 1998; Trent and Monczka, 2003). However, when suppliers are closer, it is easier to make such investments with higher pay-offs. For example, JIT is based on frequent, fast deliveries and small batches, a condition that can be difficult to obtain in a global sourcing context (Handfield, 1994). Thus, even if it is possible to achieve efficiency through global JIT, this improvement cannot be compared to what can be gained at the domestic level (Das and Handfield, 1997). Therefore, in global contexts, information sharing is usually adopted more often than system coupling (Trent and Monczka, 2003). However, the more distant suppliers are, the more difficult is to share information due to cultural and technological barriers and the possible lack of mutual trust (Hartmann et al., 2008; Ives and Jarvenpaa, 1991; Nassimbeni and Sartor, 2007).

Because of this general difficulty in performing supply chain coordination with global suppliers, several authors have focused on supply organisation and the strategy that a company should develop to effectively perform global sourcing (e.g. Faes et al., 2000; Quintens et al., 2006).

First, we can analyse the supply organisation and strategy. Some authors (e.g. Gelderman and Semeijn, 2006) found the adoption of Kraljic's purchasing portfolio approach to be beneficial to managing a global supply base. In particular, to reduce the complexity induced by global sourcing, companies try reduce the number of suppliers (e.g. Choi and Krause, 2006). However, the risks associated with global supply chains (fluctuating exchange rates, supply disruptions, strikes or political issues, lead-time variability) can be reduced using multiple supply sources (Minner, 2003), although companies must then address a larger supply base.

Next, the concept of supplier development is related to supply base reduction (Ogden, 2006). When selecting few global strategic suppliers, companies often implement vendor rating and supplier development programmes to establish a collaborative relationship with suppliers aimed at performance improvement.

All these typologies of SCMI are still in use and valid nowadays also in global contexts (e.g., Caniato et al., 2013). However, thanks to advancements in information and communication technology and the development of knowledge on SCMI and global sourcing, comparing 
2005 data (Golini and Kalchschmidt, 2011) with 2009 data we expect that companies will be more willing to adopt SCMI and that these practices should be more effective in reducing inventories. Consequently, our second and third research propositions are:

RP2. Companies adopting global sourcing are more willing to adopt SCMI in 2009 than in 2005 (Golini and Kalchschmidt, 2011).

RP3. SCMI practices have a stronger effect on reducing inventories in 2009 than in 2005 (Golini and Kalchschmidt, 2011).

Next, as shown in the introduction, limited evidence is provided regarding the extent to which this result is generally valid or whether only some types of companies are affected by the mentioned relationships. Therefore, we performed a literature review to identify the most relevant contingent variables that should be taken into account.

\subsection{Contingencies effect}

One of the main issues arising in relation with best practices in management is their applicability to different contexts. Typically, literature has investigated the best practice concept using three theoretical lenses: universalistic, contingency and configurational (Kalchschmidt, 2012; Voss, 2005). In the contingency perspective, the concept of best practice is investigated within a specific context since the impact of best practices depends on the environment in which the company operates (Ketokivi and Schroeder, 2004; Powell, 1995; Sousa and Voss, 2001, 2008).

We identified several contingent variables in the literature that can affect the relationships among global sourcing, SCMI and inventories. Our attention is devoted mainly to SCMI; thus, we focused the formulated hypotheses on the variables that may influence the relationship between (a) global sourcing and SCMI and (b) SCMI and inventories.

The variables potentially affecting these relationships can be classified into four categories: product, company, production and purchasing contingent variables (Ketokivi and Schroeder, 2004; Powell, 1995; Sousa and Voss, 2001, 2008) and we identified six relevant contingencies to which six research propositions are associated. Table 1 summarizes the considered variables that are further discussed below.

\section{TAKE IN TABLE 1}

Starting with the product variables, we found product complexity to be a relevant variable affecting sourcing decisions (Kotabe and Murray, 2004; Sharon and Eppinger, 2001). The product complexity can indeed have a twofold effect on sourcing globalisation. The less complex the product is, the easier it is to scout for and communicate with suppliers abroad (Perona and Miragliotta, 2004; Westhead et al., 2001). In contrast, when dealing with complex (i.e., technologically intense) products, companies might be forced to look for suppliers abroad, if they are not available at the local level, and exchange information with them (Chung et al., 2004). Consequently, our fourth research proposition is:

RP4. Product complexity has no effect on the relationships (a) between global sourcing and SCMI and (b) between SCMI and material inventory levels.

Regarding company variables, company size is one of the most relevant variables identified by the literature. To source globally and implement SCMI, both financial and human resources are required and larger companies have more access to these resources. Even if there are studies proving that smaller companies can also considerably adopt global sourcing, 
they can lack the resources required to perform it effectively (Cagliano et al., 2008; Cavusgil, 1980; Lee and Whang, 2000; Quintens et al., 2005). Thus, our fifth research proposition is:

RP5. Company size increases a) the effect of global sourcing on SCMI and b) the effect of SCMI on material inventory levels.

In terms of production variables, the literature considers the position of the decoupling point (Naylor et al., 1999; Olhager and Östlund, 1990). In case of assembly-to-order or make-tostock, the company operates, at least partially, in push mode, ordering materials and components in advance based on sales forecasts. This allows for it to be more efficient in managing their material inventories and consignment plans, which should ease the adoption and efficacy of SCMI compared to companies operating in engineer- or make-to-order (Gunasekaran and Ngai, 2005). Thus, our sixth research proposition is:

RP6. Make-to-stock and assembly-to-order production increases a) the effect of global sourcing on SCMI and b) the effect of SCMI on material inventory levels.

Finally, among the purchasing variables, we identified the total number of suppliers, the average number of suppliers per item and the type of products purchased as the most relevant. Having many suppliers allows them to compete with each other and prevents under-capacity issues, but can reduce supplier responsiveness (Choi and Krause, 2006; Handfield et al., 2000). In addition, having few suppliers can allow for the more effective establishment of partnerships and supply chain integration programmes (Choi and Krause, 2006). Thus, our seventh research proposition is:

RP7. The total number of suppliers reduces a) the effect of global sourcing on SCMI and b) the effect of SCMI on material inventory levels.

However, because the total number of suppliers can be related to the industry, we also considered the average number of suppliers per item as a proxy for the purchasing strategy. According to Kraljic (1983), companies should adopt single, dual, parallel or multiple sourcing strategies according to different product categories. Other contributions suggest downsizing the number of suppliers and keeping two or three suppliers per item at most (Goffin et al., 1997; Ogden, 2006). Thus, our eighth research proposition is:

RP8. The average number of suppliers per item reduces a) the effect of global sourcing on SCMI and b) the effect of SCMI on material inventory levels.

Regarding the type of purchased products, raw materials exhibit specific characteristics that differ from those of components and sub-systems. First, raw materials have a lower degree of customisation and are usually supplied by large multinational companies; therefore, creating partnerships with these companies can be difficult and not always necessary. Given the low information complexity and specificity, coupled with highly capable suppliers, the relationship with raw material suppliers is usually arms-length and based on price (Gereffi et al., 2005). This is also confirmed by Cagliano et al. (2003), who found that companies in the upstream part of the value chain tend to have a lower adoption of integration and eBusiness tools with suppliers. Thus, our ninth research proposition is:

RP9. Purchasing raw materials reduces a) the effect of global sourcing on SCMI and b) the effect of SCMI on material inventory levels.

\section{Research Method}

To address the described research propositions, we divided our empirical analysis into two parts: 
- First, we replicated the analysis of Golini and Kalchschmidt (2011) on a new sample to verify whether their results still hold (i.e., test RP 1 to 3);

- Second, we tested this model under the effect of different contingent variables to identify whether and how contingencies play a role (i.e., test RP 4 to 9).

To run the analyses we have used SPSS 20 - AMOS software. However, since some variables are not normally distributed, we validated the results through a Bollen-Stine p-value based on a 2,000-iteration bootstrap procedure (Arbuckle, 2005). This represents an additional extension of previous studies, such as Golini and Kalchschmidt (2011).

\subsection{The Sample}

To investigate the above research propositions, data were collected from the fifth edition of the International Manufacturing Strategy Survey (IMSS 5) carried out in 2009. For further information about the project, see the Appendices. The sample is described in Table 2. Specifically, 531 companies (out of the 725 included in the global database) provided information for this research, meaning that answered all the questions relevant to this study. Companies are distributed across 19 countries and are mainly small (50.5\% of the sample), although medium and large companies are also represented. Different industrial sectors from the assembly industry are considered, mainly from the manufacturing of fabricated metal products, machinery and equipment. In Golini and Kalchschmidt (2011), which used data from the previous edition of the same survey, the sample was very similar in terms of the number of observations, size and industry ${ }^{1}$, thus making their results comparable to ours.

\section{TAKE IN TABLE 2}

\subsection{Measures}

To guarantee a complete replication of the model of Golini and Kalchschmidt (2011), we designed measures based on the same items. For detailed information about the items, see the Appendices. To measure the extent of the globalisation of sourcing activities, we collected information regarding the percentage of purchases outside the continent where the plant was based.

Because we are focused on the impact of global sourcing on inventories, we considered raw material and components inventory levels. We measured the material inventory level in terms of days of production (on average) that are carried in the raw material/components inventory.

To measure SCMI, we defined a latent variable based on three items available in the questionnaire. These are single items that cover the three main areas of global SCMI identified in the literature, i.e., coordination, supply strategy and supplier development. Entering into the detail on these items, companies were asked to provide information regarding their degree of use of the following action programmes over the previous three years (on a Likert scale ranging from 1 to 5):

- Coordination: increasing the level of coordination of planning decisions and the flow of goods with suppliers, including dedicated investments (e.g., information systems, dedicated capacity/tools/equipment, dedicated workforce);

- Supply strategy: rethinking and restructuring the supply strategy and the organisation and management of the supplier portfolio through e.g., tiered networks, bundled outsourcing, and supply base reduction;

\footnotetext{
${ }^{1} 540$ companies from 23 countries; $57.8 \%$ small; $19.1 \%$ medium; $22.4 \%$ large. $39.4 \%$ ISIC $28 ; 19.1 \%$ ISIC 29; $1.7 \%$ ISIC $30 ; 12.6 \%$ ISIC $31 ; 5.6 \%$ ISIC 32; 4.3\% ISIC 33; 10.6\% ISIC 34; 6.1\% ISIC 35.
} 
- Supplier development: implementing supplier development and vendor rating programmes.

Given their high correlations (all greater than 0.5 with sig. $=0.000$ ), we incorporated these items into a unique SCMI construct. Its convergent and discriminant validity is supported by a Cronbach's alpha of 0.786 and by high factor loadings (see Table A.3 in the Appendices).

It is important to highlight that all the measures used are the same as those used by Golini and Kalchschmidt (2011), also in the way in which they are asked and measured in the questionnaire.

The descriptive statistics for all the variables are shown in Table 3. SCMI is calculated as the average of the three items described above. We can see that companies make approximately $15 \%$ of their total purchases globally, but that half of companies make $5 \%$ or less of their purchases globally, indicating a very left-skewed distribution. This confirms the low level of the diffusion of global sourcing that other studies have previously identified (Cagliano et al., 2008; Trent and Monczka, 2003). Considering inventory levels, we can see that companies hold 27 days of stock on average but that half of companies keep less than 15 days. Finally, SCMI (ranging from 1 to 5) has an average adoption of 2.97 and it is quite symmetrically distributed (Table 3 - mean and median are very close).

\section{TAKE IN TABLE 3}

We considered these variables within a structural equation model (Figure 2 and Figure A.1 in the Appendices) that replicates that of Golini and Kalchschmidt (2011).

From left to right, we can identify two paths from Global Sourcing (GS) to Material Inventory Level (MIL). Following Path 2, GS should increase the MIL (direct effect). Following Path 1, GS should positively affect Supply Chain Management Investments (SCMI), which, in turn should reduce MIL (indirect effect).

\section{TAKE IN FIGURE 2}

We tested this model on the overall sample to check whether the propositions are verified and to evaluate the total effect of GS on MIL, considering the joint effect along the two paths.

Next, to investigate RP4-9, we performed a multi-group analysis.

First, we defined groups of companies facing different contingent contexts in terms of size, type of production, type of purchases, product complexity, total number of suppliers, and average supplier per item. In order to define different groups, we had to define a threshold for each variable. For each threshold a theoretical and statistical justification has been provided.

Size was measured by the total number of employees and companies were divided according to whether they were SMEs (Group 1 - less than 250 employees) or large companies (Group 2 - more than 250 employees). The theoretical justification for the 250 threshold is the definition by the European Commission (European Commission Recommendation 2003/361/EC) according to which small and medium the enterprises are ones with less than 250 employees. The statistical justification for this threshold is the following: 
- the cluster analysis ${ }^{2}$ suggests that two clusters provide a good representation of the sample (Ketchen and Shook, 1996);

- the distribution is left-skewed, (see A.2 in the Appendices) and 250 is equal to the median value, thus this threshold is able to isolate the first group of companies from the tail (in line with Gualandris et al., 2014)

- an independent-sample t-test indicates that the means of Group 1 and 2 are significantly different (at 0.000).

The type of production was evaluated by the percentage of orders managed according to engineer-to-order (ETO), make-to-order (MTO), assembly-to-order (ATO), or make-to-stock (MTS) production systems. We calculated a composite indicator called "decoupling point" following the procedure described in Golini and Demeter (2012) and Szász and Demeter (2011) that employed the same IMSS data and indicators.

The "decoupling point" indicator is calculated as:

$$
\text { Decoupling Point }=(\% \text { ETO } \times 1)+(\% M T O \times 2)+(\% A T O \times 3)+(\% M T S \times 4)
$$

The indicator ranges from $100 \%$ (ETO only) to $400 \%$ (MTS only). We identified a threshold of $265 \%$ based on the application of a cluster analysis procedure. In particular the cluster analysis suggests that two clusters provide a good representation of the sample (Ketchen and Shook, 1996) and it identifies two clusters where the first ranges from $100 \%$ to $265 \%$ and the second from $266 \%$ to $400 \%$

The theoretical justification for the $265 \%$ threshold is that it separates companies operating mainly in ETO and MTO from those operating in ATO and MTS that is in line with the research proposition 6 .

The statistical justification for this threshold is the following:

- the distribution is not normal (Figure A.3 in the Appendices), but peaks at $100 \%$, $200 \%, 300 \%$. The value of $265 \%$ is placed in between the two peaks of $200 \%$ and $300 \%$;

- an independent-sample t-test indicates that the means of Group 1 and 2 are significantly different (at 0.000 ).

In the end, we have placed companies with a score below 265\% in Group 1 and the others in Group 2.

In terms of product complexity, we defined a new variable as the mean of four items based on a Likert scale ranging from 1 to 5: type of product design (modular or integrated); type of product (component or finished product); number of parts/components (few or many); and number of production phases (few or many). Summing these items together was justifiable because the factor's Cronbach's alpha equalled 0.72. By averaging these items, we obtained a new variable ranging from 1 to 5 and we set 3.75 as the threshold to differentiate low- (Group 1) from high-complexity (Group 2) products.

The visual analysis of the distribution (see Figure A.4 in the Appendices) does not allow the establishment of a clear cut-off point. However, we can provide the following statistical justifications:

- $\quad 3.75$ is equal to the median;

\footnotetext{
${ }^{2}$ By cluster analysis we always refer to a two-step cluster analysis using log-likelihood distance measure and Schwarz's Bayesian as the clustering criterion.
} 
- the cluster analysis suggests that two clusters provide a good representation of the sample (Ketchen and Shook, 1996) and it identifies two clusters where the first one ranges from 1 to 3.75 and the second one from 4 to 5 ;

The results are not very sensitive to this threshold because they hold even after we altered it slightly.

We defined 100 as the threshold number of suppliers to separate Group 1 from Group 2. The theoretical justification is that 100 typically considered to be a large number for a supplier base (Christy and Grout, 1994; Goffin et al., 1997). In this way, we could identify those that actually do have a very broad supplier base in Group 2. Given the left-skewed distribution (see Figure A.5 in the Appendices), the statistical justification is very similar to the one used for company size:

- the cluster analysis suggests that two clusters provide for a good representation of the sample (Ketchen and Shook, 1996);

- the distribution is left-skewed and 100 is equal to the median value, thus this treshold is able to isolate the first group of companies (in line with Gualandris et al., 2014);

- an independent-sample t-test indicates that the means of Group 1 and 2 are significantly different (at 0.000 ).

Because the total number of suppliers can depend on the type of industry, we also considered the average number of suppliers per item. In this case, we set the threshold at 2 . The theoretical justification is that a value of 2 allows us to discriminate between companies pursuing single/dual/parallel sourcing and those taking a multiple sourcing approach (Kraljic, 1983). Given the left-skewed distribution (see Figure A.6 in the Appendices), the statistical justification is similar to the previous one:

- the cluster analysis suggests that two clusters provide for a good representation of the sample (Ketchen and Shook, 1996);

- the distribution is left-skewed and 2 is equal to the median value, thus it is able to isolate the first group of companies (in line with Gualandris et al., 2014);

- an independent-sample t-test indicates that the means of Group 1 and 2 are significantly different (at 0.000 ).

Finally, we placed companies for which more than $50 \%$ of spending was used to purchase raw materials in Group 1 and all the others in Group 2 (i.e., they spend more than $50 \%$ on parts/components or subassemblies/systems). In this way we characterize those companies where raw material purchases are dominant. In this case, the visual analysis of the distribution of the variable (see Figure A.7 in the Appendices) is not helpful in determining the correctness of $50 \%$ as a cut-off point. The statistical justification is related to the following considerations:

- the average value is $52 \%$ and $50 \%$ is very close to the median value of $60 \%$;

- the cluster analysis suggests that two clusters provide for a good representation of the sample (Ketchen and Shook, 1996) and it identifies two clusters where the first one ranges from $0 \%$ to $45 \%$ and the second one from $48 \%$ to $100 \%$;

- an independent-sample t-test indicates that the means of Group 1 and 2 are significantly different (at 0.000 )

Table 4 summarises the defined groups' characteristics. 


\section{TAKE IN TABLE 4}

We then assessed the impact of contingencies on the model variables (GS, MIL, SCMI) by measuring the differences between the groups through a Mann-Whitney test (i.e., a nonparametric two independent samples test).

Finally, we performed a multiple-group analysis on the original model to assess differences between groups in terms of the structural weights - the linkages among the main variables. We adopted a procedure similar to that described in Arbuckle (2005), Cook et al. (2006), Tausch (2007). The procedure consists of the following four steps:

1. Configural equivalence: verify if the model holds when the groups are considered separately, i.e., to establish whether the factor structure and the model are valid for the different groups. To do this, no constraint is set among groups.

2. Measurement equivalence: verify if factor loadings are invariant among groups, i.e., establish whether groups perceive factors in the same way. To do this, an equality constraint is set on the measurement weights of different groups (see Figure 2 for measurement weights).

3. If the previous steps had a positive outcome, we analysed the differences among the structural weights (see Figure 2) keeping the equality constraints among measurement weights. In this way, we could assess differences among groups on the relationships (structural weights) among variables.

4. Finally, we examined the extent of the total effect of GS on MIL for the different groups.

\section{Results}

\subsection{Replication of Golini and Kalchschmidt (2011) (RP 1, 2 and 3)}

First, we replicated the model by Golini and Kalchschmidt (2011) considering the entire sample and we found that the model holds (Table 5 provides a summary of the model fit). Because the variables are non-normal (see Table A.1 in the Appendices), we validated the results through a Bollen-Stine p-value based on a 2,000-iteration bootstrap procedure.

\section{TAKE IN TABLE 5}

The factor loadings have positive and high factor scores (i.e., greater than 0.5 ) and all the structural weights are significant at the 5\% confidence level (Table 6 and A.3 in the Appendices). Moreover, the hypothesised relationships are confirmed (Table $6-2009$ Estimates). GS is associated with higher MIL by a standard estimate of 0.108 (direct effect). Furthermore, GS is related to a higher adoption of SCMI by 0.145 , which, in turn, lowers MIL by - 0.148 (indirect effect).

In conclusion, the model by Golini and Kalchschmidt (2011) still holds and the sign of the relationships among the variables is confirmed. Therefore, RP1 is confirmed. 
Considering the relationships among the variables, we can see that the coefficients have not changed significantly between 2005 and 2009 (Table 6). We tested this through the procedure described in (Cohen and Cohen, 1975). This means that RP2 and RP3 are not confirmed.

Because the coefficients are not significantly different, the total effect of GS on MIL is also very similar to that found in 2005 , equalling 0.087 (Table 7 ).

\section{TAKE IN TABLE 7}

Since the Golini and Kalchschmidt (2011) model did not include control variables, we also tested the model introducing three control variables. The first one is the GNI per capita of the country where the company is based. In particular, we have connected this variable with GS. As a matter of fact, more developed countries could have different reasons to source globally (e.g., Caniato et al., 2013). Next, we have included "low price" as a key driver for selecting suppliers (measured on a 1-5 Likert-scale) connected to GS and SCMI . Finally, we have included individualism - measured using Hofstede $(1983 ; 1991)$ - as a relevant cultural trait that can affect the willingness to share information and collaborate with suppliers (Zhao et al., 2006; Zhao et al., 2008), thus it was used to control SCMI.

When including such variables in the overall model, the model holds very well $(\mathrm{CMIN}=22.616 \mathrm{DF}=14 \mathrm{P}=0.067$; NFI $=.973$; RMSEA $=0.034)$. In particular, we found that:

- GNI is positively associated to GS;

- lowest price as a selection criteria has no effect;

- individualism is negatively associated to SCMI.

Most importantly, all the relationships among the main variables are confirmed. GS remains positively associated to SCMI and negatively to MIL, while SCMI remains negatively associated to MIL.

In order to verify possible moderation effects of GNI and individualism on the relationships among the main variables, we have also split the sample in the following groups on the basis of the median values:

- High and Low GNI (median = 32,000 \$)

- High and Low Individualism (median $=68)$

In both cases, the model holds and the results do not show significant differences in the regression weights, thus wealth and culture of the country do not seem to affect the overall model.

\subsection{Multi-Group Analysis (RP 4 to 9)}

After the overall assessment of the model, we measured the impact of contingencies on the model variables (GS, MIL, SCMI) by measuring the differences between the groups through an independent sample Mann-Whitney test (the equivalent of a t-test for non-parametric data). The results are reported in Table 8 .

\section{TAKE IN TABLE 8}

From Table 8, we can see that MIL never significantly differs among groups whereas the level of GS is always significantly different. Specifically, our sample shows that companies 
that adopt global sourcing are typically large (Size - Group 2), use ATO or MTS production systems (Type of production - Group 2), have a lower share of raw materials purchases (Type of purchases - Group 2), have high product complexity (Product complexity- Group 2) and work with several suppliers in total (Number of suppliers - Group 2), but with few per item (Avg. suppliers per item - Group 2). This profile makes perfect sense as larger companies dealing with complex products usually have more suppliers, but they also manage more components so their average number of suppliers per item can be low. SCMI are also significantly different between the two considered groups, with the only exception of the number of suppliers per item, which does not show any significant difference in terms of SCMI. This is quite surprising as SCMI is usually related to a supply base reduction.

As explained in the methodology, we then assessed configural and measurement equivalence. The models used to assess equivalence always have (i.e., for any considered contingency variable) a good fit that tends to increase when constraining measurement weights. Specifically, RMSEA is always lower that 0.05 , NFI is higher than 0.974 and CFI is higher than 0.990 (Table A.2 in the Appendices provides details on measures of fit). This result is also confirmed by a bootstrap analysis (Bollen-Stine p-value) to overcome possible nonnormality issues. By means of a chi-square test, we assessed that the increase in fit is significant, meaning that considering the measurement weights to be identical among the groups improves the fit of the model. In conclusion, the model and the factors hold for different groups for all the contingencies. We then turned to analyse differences in the structural weights.

We compared the regression coefficients between the groups, constraining the models to have identical measurement weights (Table 9).

\section{TAKE IN TABLE 9}

Looking at Table 9, we put specific attention to the relationships between GS and SCMI and between SCMI and MIL that are the focus of our propositions. More in detail, for each contingent variable, these relationships are significant only for one group at a time:

- Large companies (size - group 2), confirming RP5a\&b;

- ATO/MTS companies (type of production - group 2), confirming RP6a\&b;

- Companies with less than 100 suppliers (number of suppliers - group 1), confirming RP7a\&b;

- Companies with less than 2 suppliers per item (average number of suppliers - group 1), confirming RP8a\&b.

- Companies with a high share of raw material purchases (type of purchases - group 1), contradicting RP9a\&b

For the other groups (small companies, ETO/MTO companies, companies with more than 100 suppliers and companies with a low share of raw material purchases), the relationships between GS and SCMI and between SCMI and MIL are never significant.

Considering complexity, we found that the relationships are only partially confirmed for both groups. In particular, companies characterised by low-complexity products (group 1) do not systematically invest in SCMI even if it could be beneficial for reducing MIL. Because we stated that product complexity has no effect on the relationships (a) between global sourcing and SCMI and (b) between SCMI and material inventory levels, RP4a\&b are not confirmed. 
Finally we analysed the total effect of GS on MIL (Table 10). We can see that the overall effect, when significant, is always positive even if it shows differences among the considered contingency-based groups. In the next section, these results are discussed further.

TAKE IN TABLE 10

\section{Discussion}

The empirical analysis provides interesting insights regarding the complex relationships among global sourcing, supply chain investments and material inventories.

First, the results provided in Golini and Kalchschmidt (2011) are confirmed; thus, the replication of the study confirms that the impact of global sourcing on material inventory levels is reduced by SCMI that, at least partially, reduce the negative effect of global sourcing (i.e., increase of material inventory levels). The provided statistics also confirm the intensity of the relationships (see Table 6). Replication is an important part of the scientific process (Frohlich and Westbrook, 2001): theory-building must be followed by rounds of verification and elaboration (Flynn et al., 1990). In particular, quickly evolving issues such as globalisation need to be monitored to test the robustness of initial findings and to eventually identify evolutionary trends. In our case, the comparison between 2005 and 2009 shows that companies adopting global sourcing, compared to those adopting local sourcing, are not more willing to adopt SCMI and that SCMI do not have a stronger effect on material inventory levels. Moreover, we were also able to improve the evaluation and analysis of the considered model and we verified its generalizability. Specifically, we found that these results hold for different countries in terms of economic development (developed and developing) and culture (individualist or collectivist). This result is particularly important since it guarantees that our findings have not been influenced by the considered sample: in fact, the results hold for samples collected in different periods of time - Golini and Kalchschmidt (2011) refer to data collected during 2005 while in the case at hand data was collected during 2009 - with different companies involved (less than $10 \%$ of the sample is made of companies that participated to both processes of data collection). We argue that this result suggests, especially at the global level, that there is still the need for research and practice to clearly define the best practices in supply chain management.

Second, we identified that the impact of the analysed contingencies is very relevant and that the total effect of GS on MIL can change from case to case. When introducing these factors, the relationships between the variables in the model become either very strong or very weak. In particular, the mentioned relationships are stronger for larger companies, companies with a limited number of suppliers, companies characterised by ATO or MTS production processes and companies that mainly purchase raw materials. Product complexity has instead a mixed effect. Discussion of these results is detailed in the following for each considered contingent variable.

\section{Company size}

Larger companies - i.e., those with more than 250 employees - benefit significantly from SCMI and for this reason they tend to adopt GS to a larger extent. In fact, larger companies adopt both practices (i.e. GS and SCMI) significantly more than small companies (see Table 8) and they have similar inventory levels. Despite the fact that there are studies proving that 
smaller companies can also considerably adopt global sourcing, our findings support the idea that they can lack the resources required to perform it effectively (Cagliano et al., 2008; Cavusgil, 1980; Lee and Whang, 2000; Quintens et al., 2005). Moreover, the relationships among the different variables are strong and significant for large companies indicating that the compensation effect of SCMI applies for them. As a matter of fact, the direct effect of GS on MIL is larger (0.169 - Table 9) than the actual total effect $(0.145$ - Table 10), meaning that GS has a strong impact on MIL that cannot be compensated by the indirect effect. On the contrary, when companies are smaller, they adopt global sourcing to a very limited extent (Table 8) and the effect of GS on MIL is not significant (Tables 9 and 10). This result suggests that, in a global sourcing context, larger companies are able to benefit from SCMI more than smaller companies, thereby highlighting the importance for smaller companies of investing carefully in SCMI since a positive pay-off is not guaranteed. We argue that this results also suggests that smaller companies should try to share risks with other partners and look for collaborations to make SCMI more effective. The conditions under which this indication really applies and how companies should effectively share risks, however, is a potentially interesting topic for future studies. For instance, it would be interesting to verify if risk sharing is performed in collaboration with partners from the same supply chain or geographical area.

\section{Type of production}

Companies based on ATO or MTS production systems tend to adopt GS and SCMI more compared to those companies that rely on ETO and MTO systems. In this case, the beneficial impact of SCMI on MIL is very high (std. estimate is -.302). The higher adoption of SCMI by these companies (Table 8) can be related not only to the higher adoption of global sourcing, but also to the relevant implications of out-of-stock situations on production continuity. In contrast, ETO/MTO companies behave similarly to small companies, i.e., they have a limited adoption of GS and its relationships with the other variables are so weak that they are not significant. This result suggests that global sourcing and its proper management are key issues for companies that decide to organize with ATO or MTS production systems. Partially we can also consider that companies that organize around ETO/MTO systems are likely to reduce the adoption of global sourcing since it will imply issues that are difficult to solve just through SCMI. For example, delivery time can be a big issue in a MTO situation if long lead-times are required. In these cases companies often prefer to manage their supply chains differently e.g. locating production facilities abroad to serve foreign markets.

\section{Type of purchased materials}

Despite the beneficial effect of SCMI on MIL, companies that buy mainly raw materials (i.e. more upstream in the supply chain) tend to adopt GS and SCMI to a smaller extent compared to those companies that purchase mainly subassemblies (i.e., more downstream in the supply chain). This can be related to the established relationships with large raw materials suppliers in the same continent, that, however, are not very willing to integrate the supply chain with their customers. In this case, the position in the supply chain and the typology of suppliers is a barrier towards supply chain integration and globalization. On the contrary, companies purchasing mainly subassemblies, do not gain benefits from SCMI in terms of MIL, however it looks easier for them to invest in the supply chain and tolerate higher levels of globalization without holding more inventories (Table 8). 


\section{Product complexity}

Companies making complex products tend to adopt both GS and SCMI more extensively. We can argue that the higher complexity is directly related to the higher adoption of GS since it can be difficult to find all the components locally. Quite interestingly, however, SCMI is beneficial in reducing MIL only for lower complexity products. By consequence, companies making simpler products achieve similar results by investing less. In summary, companies dealing with complex products face a more difficult situation as they might be forced to source globally, while at the same time they have to invest significantly more in SCMI in order to keep their inventories low.

\section{Number of suppliers}

In this case, companies that leverage on more suppliers - i.e., more than 200 suppliers - tend also to use GS and SCMI more intensively. In fact, if the company wants to enlarge the supply base, it has to look abroad since locally available suppliers are limited. As a consequence, to manage such a complex supply base, these companies need also to invest more in SCMI. One might expect that companies with a larger supplier base might also strongly benefit from tools enhancing their coordination. However, as highlighted by the relevant literature (Goffin et al., 1997; Ogden, 2006), a large supply base can cause ineffectiveness. In fact, for these companies, SCMI does not lead to a lower MIL. Only for companies with a limited number of suppliers - i.e., less than 100 suppliers - the impact of SCMI on MIL is high and significant (std. estimate is -.226). This means that when only a limited number of suppliers are selected, companies can leverage on SCMI more easily.

\section{Average number of suppliers per item}

Similarly, companies with a simpler supply base - i.e., less that 2 suppliers per item on average, are able to extend globally their sourcing and keep inventories low with the same investment than companies with more suppliers (Table 8). This means that, the beneficial effect of SCMI for the former companies is so relevant that, even if they use GS more, the level of inventory is perfectly comparable. We can also hypothesise that for these companies, SCMI are adopted for reasons other than reducing inventories: for instance, to establish close relationships and communicate with the few global suppliers in their portfolios. This also indicates that when fewer suppliers have to be managed, fewer SCMI are likely to be needed.

By looking at the overall results, it is evident that managing global sourcing is a contingent issue and that companies should pay attention to their supply chain investment beforehand. This point is critical since companies frequently decide to invest in their supply chain and in its globalization without giving this decision the proper attention. In the last years, companies have decided to move parts of their operations abroad and extend their supply chain to other countries due to myopic analysis or by following what other companies were doing. The "fad and fashion" concept \{Abrahamson, 1991 \#233\} is often mentioned in this context to indicate that companies may decide to adopt specific practices since their competitors or closer companies have adopted them. Our results highlight that, since the specific context is critical in influencing how global sourcing and supply chain management investments are applied, their effectiveness is context specific and thus should be carefully evaluated. Our analysis highlights conditions that relate to the effectiveness of SCMI and thus is meant to provide guidance for companies in deciding when and how to invest. 


\section{Conclusions}

This paper contributes to the research on the impact of globalisation on company operations. Specifically, attention is devoted to the effect of supply chain investment on the relationship between global sourcing and material inventory levels. The paper confirms the results found in Golini and Kalchschmidt (2011) using updated data and thus confirms that the impact of global sourcing on inventory levels is reduced by SCMI. Furthermore, this work extends the previous model by considering contingent factors and their moderating effect on the considered relationships. Specifically, this study provides evidence that SCMI have a more beneficial effect on inventory levels for larger companies, companies with a limited number of suppliers, companies characterised by ATO or MTS production processes and companies that mainly purchase raw materials. So we identify that in some specific conditions investing in SCM has a clear and important effect on inventory performance. In other situations, on the contrary, there is no one best way to keep inventory under control, but different solutions may have similar effects. Specifically, for smaller companies, operating with several suppliers, characterised by ETO or MTO production processes or purchasing mainly subassemblies, investments on SCM and global sourcing have different effects that depend from other leverages companies have to consider. The paper thus provides an original contribution to the current literature on the impact of globalisation (specifically global sourcing) on company performance (i.e., material inventory levels).

From a theoretical point of view, this work stresses that global supply chain management should be approached according to a contingent perspective. Even if literature, in general, suggests that investing in supply chain management has a positive impact, we show that this implication is not always straightforward. In particular, we argue that the evaluation of benefits of supply chain investments should be analysed considering the internal context in which companies are operating and thus the one-fit-for-all solutions should be considered with caution.

These results have also several managerial implications. First, larger companies that leverage on few suppliers, are upstream in the supply chain and use ATO or MTS production processes should put more effort towards developing relationships with foreign suppliers because they can benefit more from these investments. In contrast, when companies have multiple suppliers, have order-based production processes and purchase complex goods, whether SCMI have a real and relevant impact on inventories is not as clear. In this second case, companies need to develop specific analyses and evaluations to assess whether SCMI would be beneficial.

The paper also indicates that, in some contexts, the relationships among the mentioned variables are not clear, which suggests that future research should explore these conditions in more detail. When smaller companies are considered, SCMI may not be worthwhile if operating in a global sourcing context due to the significant required investments that may not be justified by the small scale of the company. Similarly, when purchased goods are extremely complex and custom-made, SCMI benefits may not relate to inventory levels but rather to other outcomes such as delivery time, product customisation and purchasing costs. Again, this suggests that in these situations, an appropriate investment analysis should be specifically designed.

Finally, we would like to highlight some of the limitations of this study. First, we did not consider the costs that supply chain management investments may imply. This work addresses the impact of supply chain investments in improving company performance. However, supply chain investments imply costs and often lead to higher managerial complexity; for these reasons, companies may be not willing to make significant investments, 
specifically when the cost-benefit trade-off is not positive. We argue that thus future works should address this topic directly, even if we are aware of the complexity of the evaluation of the value of supply chain investments. Second, our dataset includes companies only from the manufacturing sector, although the ISIC code range is relatively wide. Different outcomes could be found in other types of industries and thus the extension of this analysis also to other sectors would be important. In the end, only some contingency variables were taken into account: attention was paid to contingency variables that are considered to be relevant in the global sourcing literature. Other variables may be significant and thus exploratory research would be important to identify other relevant contingent factors. In addition, contingent variables could be interrelated, e.g., a higher complexity product could be related to a higher number of suppliers, which could be taken into account in subsequent studies. Thus additional analyses would allow to extent and better interpret our results.

\section{References}

Adair-Heeley, C.B., 1988. JIT purchasing: seven steps for successful implementation. Production and Inventory Management Review and APICS News 8 (12), 22-23.

Arbuckle, J.L., 2005. Amos 6.0 user's guide. Chicago: SPSS.

Babbar, S., Prasad, S., 1998. International purchasing, inventory management and logistics research. International Journal of Operations \& Production Management 18 (1), 6-36.

Bozarth, C., Handfield, R., Das, A., 1998. Stages of global sourcing strategy evolution: an exploratory study. Journal of Operations Management 16 (2-3), 241-255.

Bygballe, L.E., Bøa, E., Grønland, S.E., 2011. Managing international supply: The balance between total costs and customer service. Industrial Marketing Management.

Cagliano, R., Caniato, F., Golini, R., Kalchschmidt, M., Spina, G., 2008. Supply chain configurations in a global environment: A longitudinal perspective. Operations Management Research 1 (2), 86-94.

Cagliano, R., Caniato, F., Spina, G., 2003. E-business strategy: how companies are shaping their supply chain through the internet. International Journal of Operations \& Production Management 23 (10), 1142-1162.

Caniato, F., Cagliano, R., Kalchschmidt, M., Golini, R., Spina, G., 2009. Evolutionary patterns in e-business strategy. International Journal of Operations \& Production Management 29 (9), 921-945.

Caniato, F., Golini, R., Kalchschmidt, M., 2013. The effect of global supply chain configuration on the relationship between supply chain improvement programs and performance. International Journal of Production Economics 143 (2), 285-293.

Carter, J.R., Vickery, S.K., 1989. Currency exchange rates: their impact on global sourcing. Journal of Purchasing and Materials Management 25 (3), 19-25.

Cavusgil, S.T., 1980. On the internationalization process of firms. European Research 8 (6), 273-281.

Choi, T.Y., Krause, D.R., 2006. The supply base and its complexity: Implications for transaction costs, risks, responsiveness, and innovation. Journal of Operations Management 24 (5), 637-652.

Christy, D.P., Grout, J.R., 1994. Safeguarding supply chain relationships. International Journal of Production Economics 36 (3), 233-242.

Chung, W.W.C., Yam, A.Y.K., Chan, M.F.S., 2004. Networked enterprise: A new business model for global sourcing. International Journal of Production Economics 87 (3), 267-280.

Cohen, J., Cohen, P., 1975. Applied multiple regression/correlation analysis for the behavioral sciences. Lawrence Erlbaum. 
Cook, A.J., Brawer, P.A., Vowles, K.E., 2006. The fear-avoidance model of chronic pain: validation and age analysis using structural equation modeling. Pain 121 (3), 195-206.

Dornier, P.P., Ernst, R., Fender, M., Kouvelis, P., 2008. Global operations and logistics: Text and cases. Wiley-India.

Faes, W., Matthyssens, P., Vandenbempt, K., 2000. The pursuit of global purchasing synergy. Industrial Marketing Management 29 (6), 539-553.

Fawcett, S.E., Magnan, G.M., McCarter, M.W., 2008. Benefits, barriers, and bridges to effective supply chain management. Supply Chain Management: An International Journal 13 (1), 35-48.

Fisher, M.L., 2003. What is the right supply chain for your product? Operations management: critical perspectives on business and management 105, 73.

Flynn, B.B., Sakakibara, S., Schroeder, R.G., Bates, K.A., Flynn, E.J., 1990. Empirical research methods in operations management. Journal of Operations Management 9 (2), 250284.

Frear, C.R., Metcalf, L.E., Alguire, M.S., 1992. Offshore sourcing: its nature and scope. International Journal of Purchasing and Materials Management 28 (3), 2-11.

Frohlich, M.T., Westbrook, R., 2001. Arcs of integration: An international study of supply chain strategies. Journal of Operations Management 19 (2), 185-200.

Gelderman, C.J., Semeijn, J., 2006. Managing the global supply base through purchasing portfolio management. Journal of Purchasing and Supply Management 12 (4), 209-217.

Gereffi, G., Humphrey, J., Sturgeon, T., 2005. The governance of global value chains. Review of international political economy 12 (1), 78-104.

Goffin, K., Szwejczewski, M., New, C., 1997. Managing suppliers: when fewer can mean more. International Journal of Physical Distribution \& Logistics Management 27 (7), 422436.

Golini, R., Demeter, K., 2012. Determinants of input, work-in-process and output inventory levels: an international study of manufacturing industries, 17th International Symposium on Inventories, Budapest (Hungary).

Golini, R., Kalchschmidt, M., 2011. Moderating the impact of global sourcing on inventories through supply chain management. International Journal of Production Economics 133 (1), 86-94.

Gualandris, J., Golini, R., Kalchschmidt, M., 2014. Do supply management and global sourcing matter for firm sustainability performance? An international study. Supply Chain Management: An International Journal 19 (3), 258-274.

Guariglia, A., 1999. The Effects of Financial Constraints on Inventory Investment: Evidence from a Panel of UK Firms. Economica 66 (261), 43-62.

Gunasekaran, A., Ngai, E.W.T., 2005. Build-to-order supply chain management: a literature review and framework for development. Journal of Operations Management 23 (5), 423-451. Han, C., Dresner, M., Windle, R.J., 2008. Impact of global sourcing and exports on US manufacturing inventories. International Journal of Physical Distribution \& Logistics Management 38 (6), 475-494.

Handfield, R., Krause, D., Scannell, T., Monczka, R.M., 2000. Avoid the pitfalls in Supplier Development. Sloan Management Review 41 (2), 37-49.

Handfield, R.B., 1994. US global sourcing: patterns of development. International Journal of Operations \& Production Management 14, 40-40.

Harris, F.W., 1913. How many parts to make at once. Factory, The Magazine of Management $10(2), 135-136$.

Hartmann, E., Trautmann, G., Jahns, C., 2008. Organisational design implications of global sourcing: A multiple case study analysis on the application of control mechanisms. Journal of Purchasing and Supply Management 14 (1), 28-42. 
Hendricks, K.B., Singhal, V.R., 2005. An Empirical Analysis of the Effect of Supply Chain Disruptions on Long Run Stock Price Performance and Equity Risk of the Firm. Production and Operations Management 14 (1), 35-52.

Hofstede, G., 1983. The cultural relativity of organizational practices and theories. Journal of International Business Studies 14 (2), 75-89.

Hofstede, G., Hofstede, G.J., Minkov, M., 1991. Cultures and Organizations: Software of the Mind, revised and expanded 3rd ed. McGraw-Hill, New York, NY.

Holweg, M., Reichhart, A., Hong, E., 2011. On risk and cost in global sourcing. International Journal of Production Economics 131 (1), 333-341.

Hülsmann, M., Grapp, J., Li, Y., 2008. Strategic adaptivity in global supply chains-

Competitive advantage by autonomous cooperation. International Journal of Production

Economics 114 (1), 14-26.

Ives, B., Jarvenpaa, S.L., 1991. Applications of global information technology: key issues for management. MIS Quarterly 15 (1), 33-49.

Kalchschmidt, M., 2012. Best practices in demand forecasting: Tests of universalistic, contingency and configurational theories. International Journal of Production Economics 140 (2), 782-793.

Ketchen, D.J., Shook, C.L., 1996. The application of cluster analysis in strategic management research: an analysis and critique. Strategic Management Journal 17 (6), 441-458.

Ketokivi, M.A., Schroeder, R.G., 2004. Strategic, structural contingency and institutional explanations in the adoption of innovative manufacturing practices. Journal of Operations Management 22 (1), 63-89.

Kotabe, M., Murray, J.Y., 2004. Global sourcing strategy and sustainable competitive advantage. Industrial Marketing Management 33 (1), 7-14.

Kotabe, M., Omura, G.S., 1989. Sourcing Strategies of European and Japanese

Multinationals: A Comparison. Journal of International Business Studies 20 (1), 113-130.

Kraljic, P., 1983. Purchasing must become supply management. Harvard Business Review 61 (5), 109-117.

Krause, D.R., Handfield, R.B., Scannell, T.V., 1998. An empirical investigation of supplier development: reactive and strategic processes. Journal of Operations Management 17 (1), 3958 .

Lai, G., Debo, L.G., Sycara, K., 2009. Sharing inventory risk in supply chain: The implication of financial constraint. Omega 37 (4), 811-825.

Lee, H.L., Whang, S., 2000. Information sharing in a supply chain. International Journal of Manufacturing Technology and Management 1 (1), 79-93.

MacCarthy, B.L., Atthirawong, W., 2003. Factors affecting location decisions in international operations a Delphi study. International Journal of Operations \& Production Management 23 (7/8), 794-819.

Meixell, M.J., Gargeya, V.B., 2005. Global supply chain design: A literature review and critique. Transportation Research 41 (6), 531-550.

Minner, S., 2003. Multiple-supplier inventory models in supply chain management: A review. International Journal of Production Economics 81-82, 265-279.

Monczka, R.M., Trent, R.J., 1991. Global sourcing: a development approach. International Journal of Purchasing and Materials Management 27 (2), 2-8.

Narasimhan, R., Mahapatra, S., 2004. Decision models in global supply chain management. Industrial Marketing Management 33 (1), 21-27.

Nassimbeni, G., Sartor, M., 2007. Sourcing in China: a typology. International Journal of Production Economics 107 (2), 333-349. 
Naylor, B.J., Naim, M.M., Berry, D., 1999. Leagility: integrating the lean and agile manufacturing paradigms in the total supply chain. International Journal of Production Economics 62 (1), 107-118.

Ogden, J.A., 2006. Supply base reduction: An empirical study of critical success factors. Journal of Supply Chain Management 42 (4), 29-39.

Olhager, J., Östlund, B., 1990. An integrated push-pull manufacturing strategy. European Journal of Operational Research 45 (2-3), 135-142.

Perona, M., Miragliotta, G., 2004. Complexity management and supply chain performance assessment. A field study and a conceptual framework. International Journal of Production Economics 90 (1), 103-115.

Powell, T.C., 1995. Total quality management as competitive advantage: a review and empirical study. Strategic Management Journal 16 (1), 15-37.

Power, D., 2005. Supply chain management integration and implementation: a literature review. Supply Chain Management: An International Journal 10 (4), 252-263.

Quintens, L., Matthyssens, P., Faes, W., 2005. Purchasing internationalisation on both sides of the Atlantic. Journal of Purchasing and Supply Management 11 (2-3), 57-71.

Quintens, L., Pauwels, P., Matthyssens, P., 2006. Global purchasing strategy:

Conceptualization and measurement. Industrial Marketing Management 35 (7), 881-891.

Shah, R., Ward, P.T., 2003. Lean manufacturing: context, practice bundles, and performance. Journal of Operations Management 21 (2), 129-149.

Sharon, N., Eppinger, S.D., 2001. Sourcing by Design: Product Complexity and the Supply Chain. Management Science 47 (1), 189-204.

Sheth, J.N., Sharma, A., 1997. Supplier relationships: emerging issues and challenges. Industrial Marketing Management 26 (2), 91-100.

Skjott-Larsen, T., Schary, P.B., 2007. Managing the global supply chain. Copenhagen Business School Press.

Sousa, R., Voss, C.A., 2001. Quality management: universal or context dependent?

Production and Operations Management 10 (4), 383-404.

Sousa, R., Voss, C.A., 2008. Contingency research in operations management practices. Journal of Operations Management 26 (6), 697-713.

Steinle, C., Schiele, H., 2008. Limits to global sourcing? Strategic consequences of dependency on international suppliers: Cluster theory, resource-based view and case studies. Journal of Purchasing and Supply Management 14 (1), 3-14.

Stratton, R., Warburton, R.D.H., 2006. Managing the trade-off implications of global supply. International Journal of Production Economics 103 (2), 667-679.

Szász, L., Demeter, K., 2011. Supply chain position and servitization efforts of companies in Eastern and Western Europe. Journal of International Business and Economics 11 (1), 104112.

Tan, K.C., 2001. A framework of supply chain management literature. European Journal of Purchasing \& Supply Management 7 (1), 39-48.

Tausch, N., Hewstone, M., Kenworthy, J., Cairns, E., Christ, O., 2007. Cross-community contact, perceived status differences, and intergroup attitudes in Northern Ireland: The mediating roles of individual-level versus group-level threats and the moderating role of social identification. Political Psychology 28 (1), 53-68.

Trent, R.J., Monczka, R.M., 2003. Understanding integrated global sourcing. International Journal of Physical Distribution \& Logistics Management 33 (7), 607-629.

Voss, C.A., 2005. Alternative paradigms for manufacturing strategy. International Journal of Operations \& Production Management 25 (12), 1211.

Watts, C.A., Hahn, C.K., 1993. Supplier development programs: an empirical analysis. Journal of Supply Chain Management 29 (2), 10-17. 
Westhead, P., Wright, M., Ucbasaran, D., 2001. The internationalization of new and small firms:: A resource-based view. Journal of Business Venturing 16 (4), 333-358.

Zhao, X., Flynn, B.B., Roth, A.V., 2006. Decision Sciences Research in China: A Critical Review and Research Agenda - Foundations and Overview. Decision Sciences 37 (4), 451496.

Zhao, X., Huo, B., Flynn, B.B., Yeung, J.H.Y., 2008. The impact of power and relationship commitment on the integration between manufacturers and customers in a supply chain. Journal of Operations Management 26 (3), 368-388. 


\section{Appendices}

Figure A. 1- Structural equation model

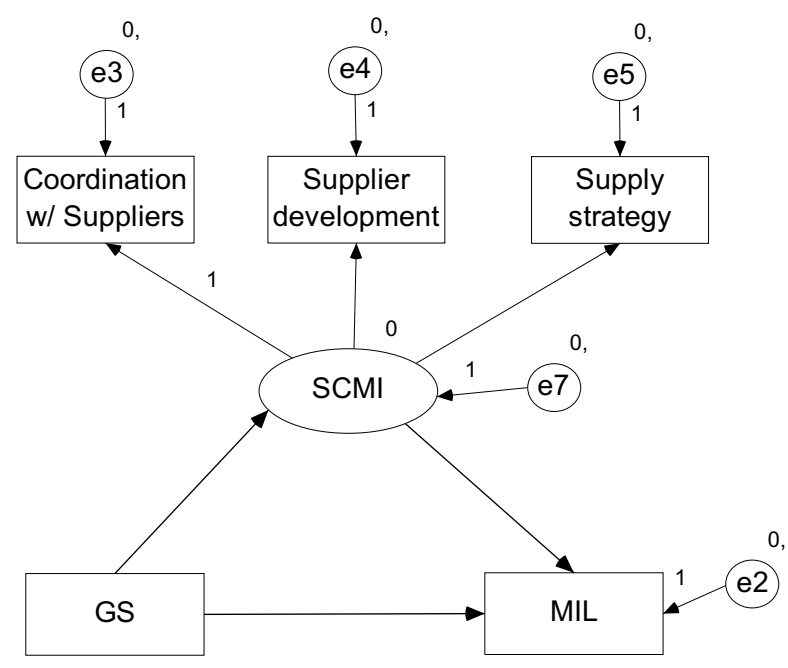

Figure A.2 - Distribution of company size (only firms with less of 2000 employees are displayed)

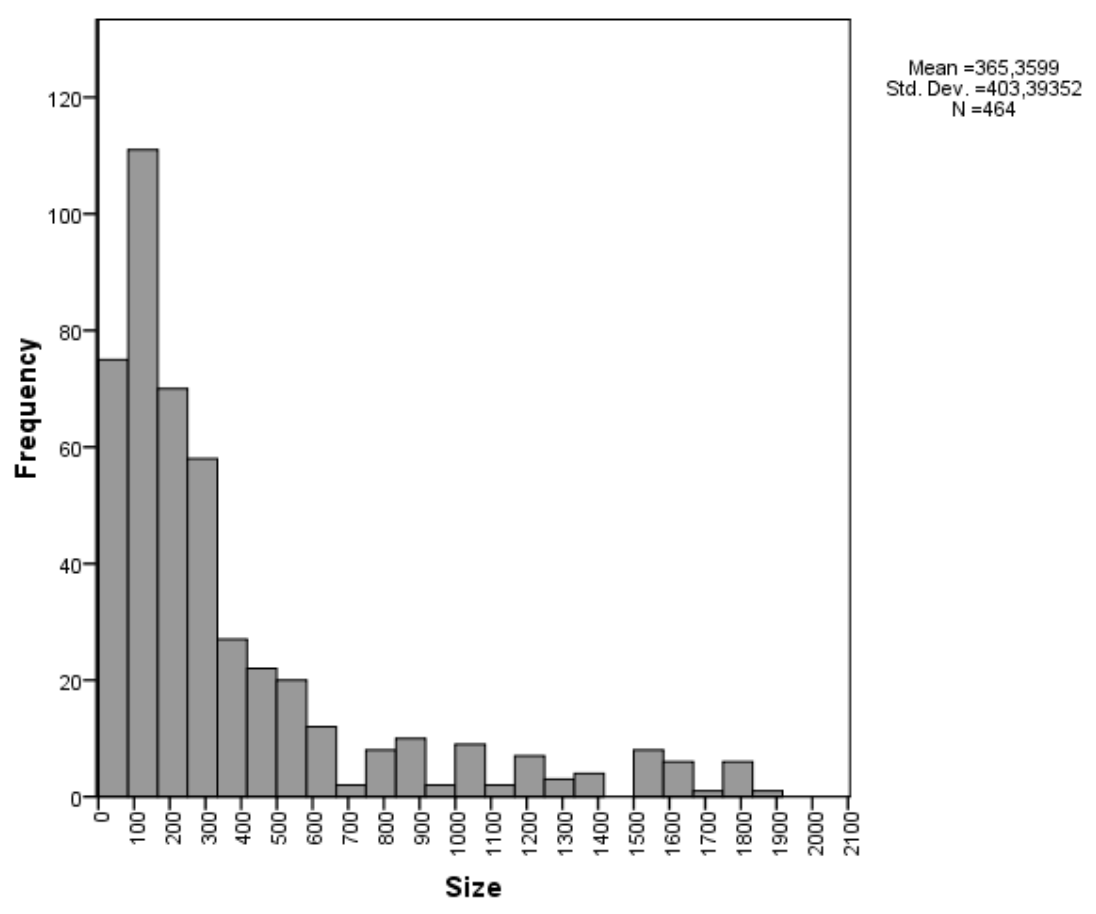


Figure A.3 - Distribution of the variable "decoupling point"

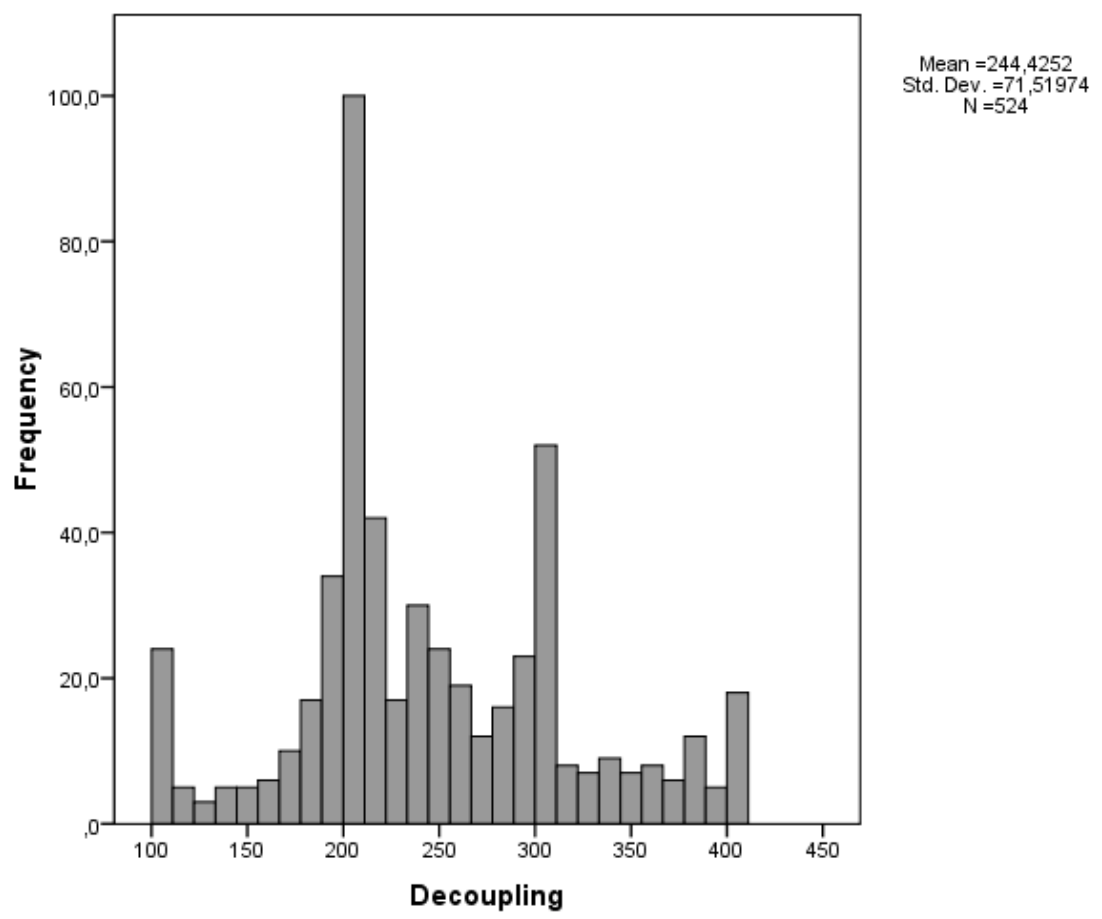

Figure A.4 - Distribution of the variable "complexity"

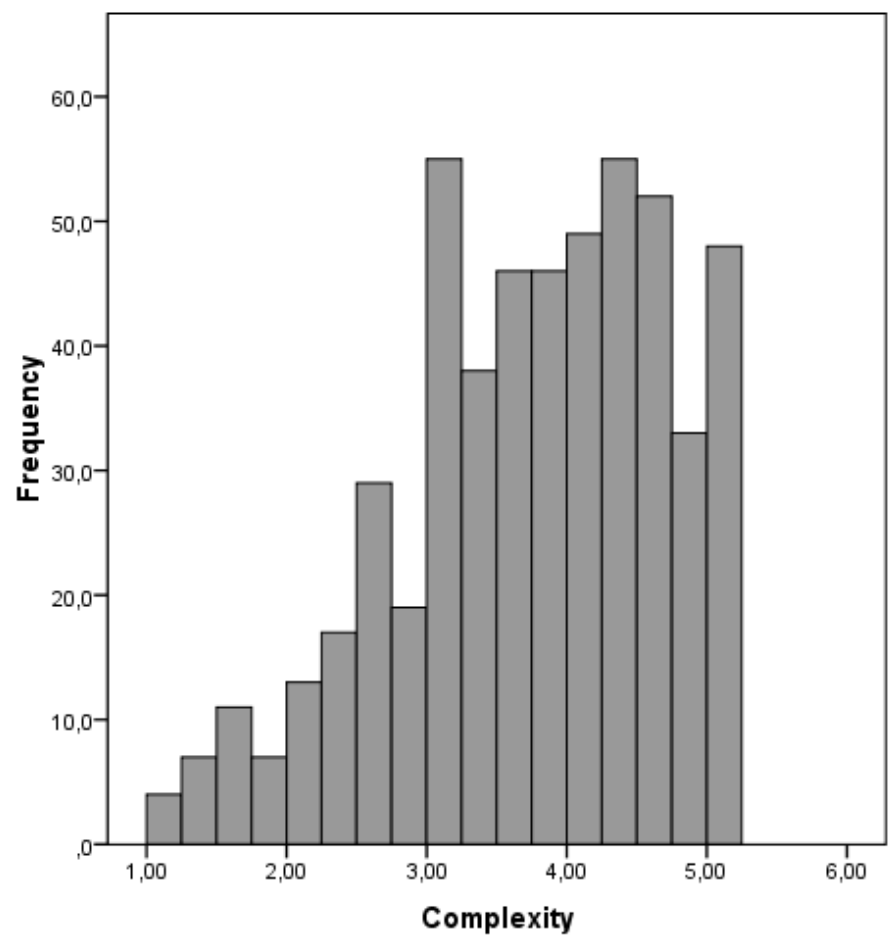

Mean $=3,6181$

Dev. $=9599$ 
Figure A.5 - Distribution of the variable "total number of suppliers"

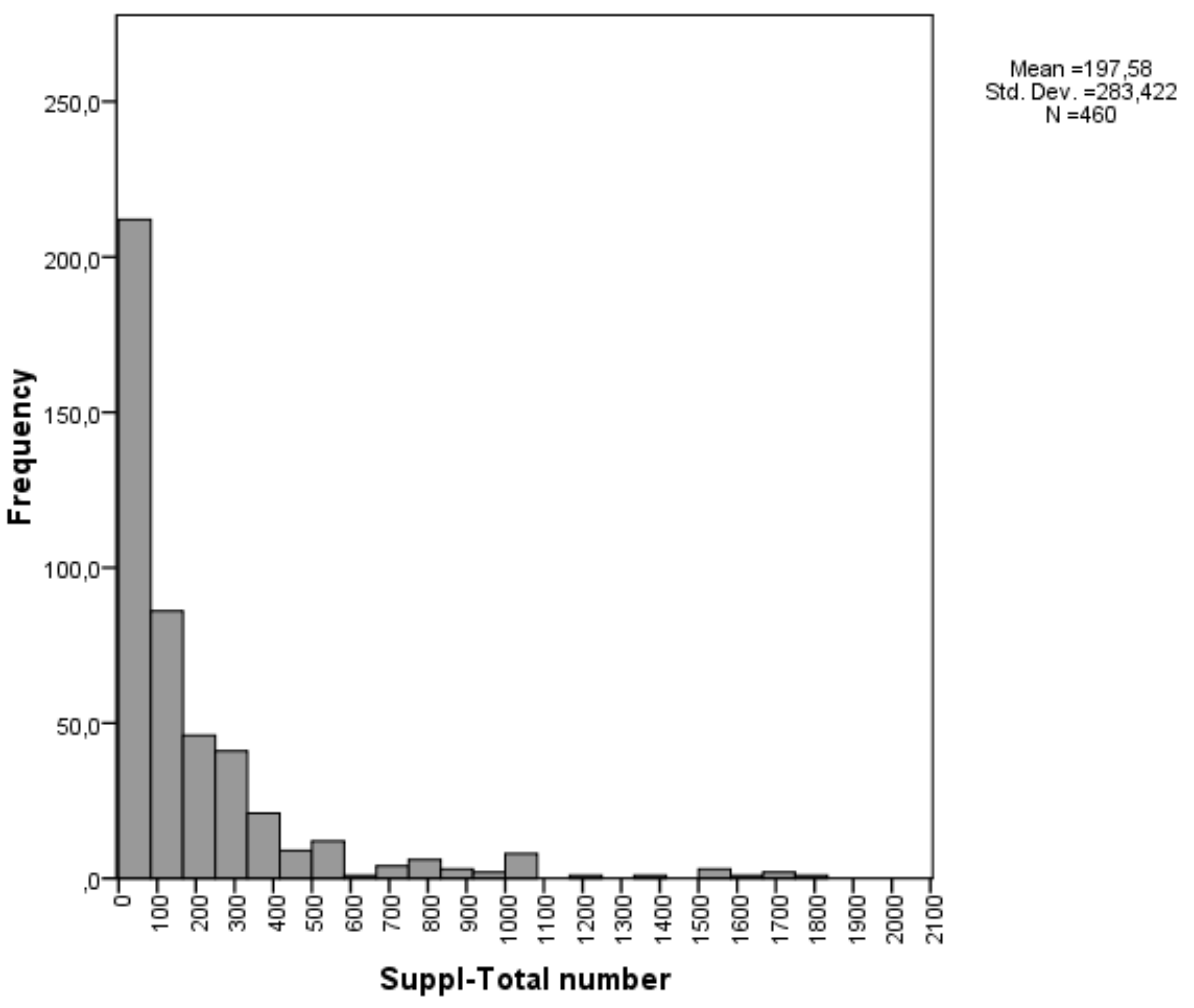

Figure A.6 - Distribution the variable average number of suppliers per item

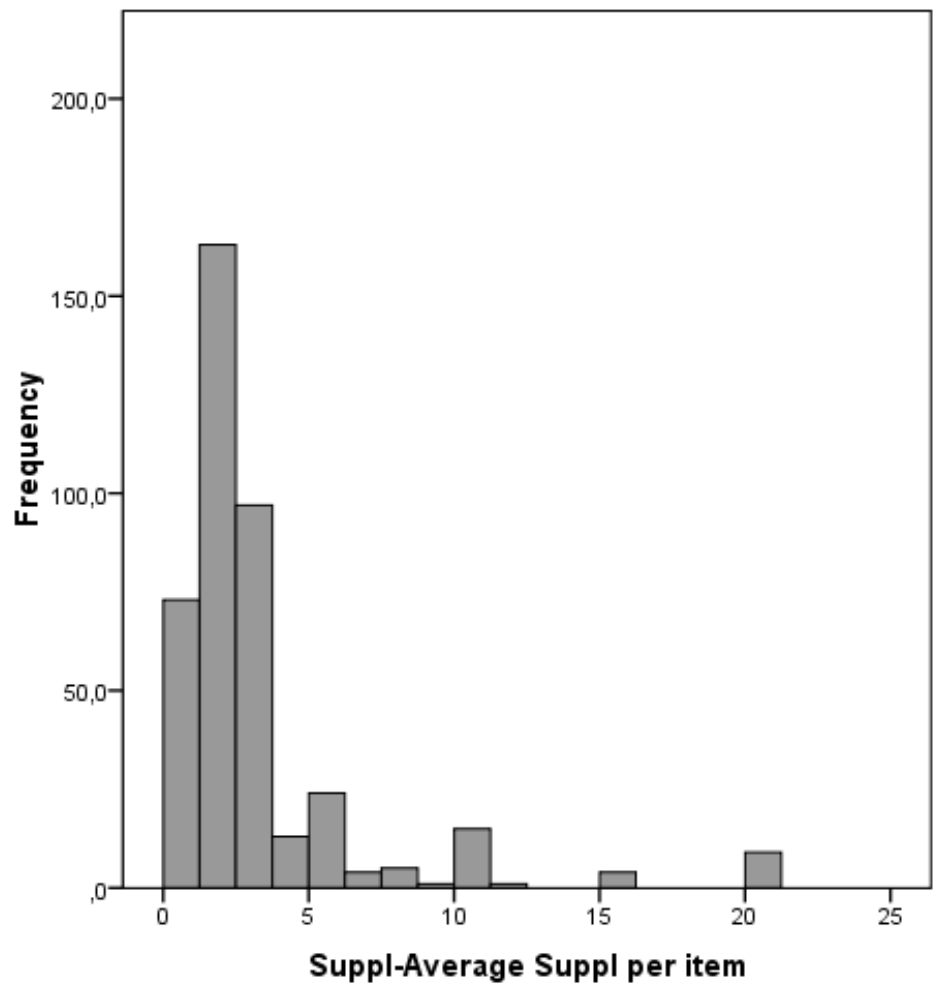

Mean $=3,25$

Suppl-Average Suppl per item 
Figure A.7 - Distribution of the variable "percentage of raw materials in relation to total spending"

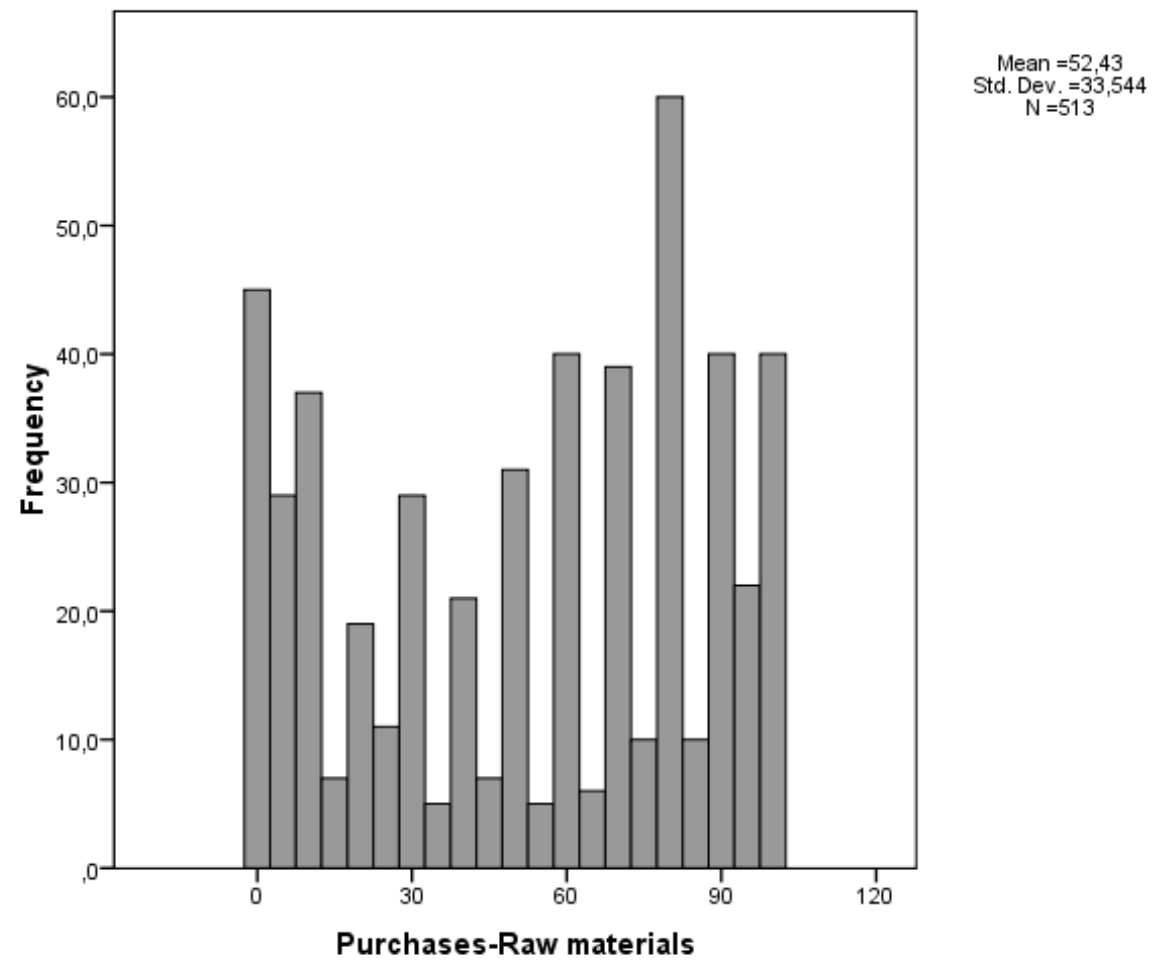

Table A. 1 - Skewness and kurtosis (a ratio higher than 2 or lower than - 2 is considered a significant departure from a normal distribution, while higher than 10 or lower than -10 is considered a severe non-normality)

\begin{tabular}{lcccc}
\hline Variable & skew & \multicolumn{1}{c}{ c.r. } & kurtosis & c.r. \\
\hline GS & 1.864 & 17.540 & 3.110 & 14.629 \\
Coordination w/ Suppliers & -.024 & -.221 & -.826 & -3.887 \\
Supplier Development & -.076 & -.711 & -.879 & -4.134 \\
Supplier Strategy & -.121 & -1.135 & -.826 & -3.886 \\
MIL & 2.557 & 24.054 & 8.565 & 40.285 \\
\hline
\end{tabular}


Table A. 2 - Configural and measurement equivalence models fit.

\begin{tabular}{lccccccc}
\hline & chi-square & df & p-value & $\begin{array}{c}\text { Bollen- } \\
\text { Stine p- } \\
\text { value }\end{array}$ & RMSEA & NFI & CFI \\
\hline $\begin{array}{l}\text { Size } \\
\quad \text { Configural equivalence }\end{array}$ & 6.740 & 8 & .565 & .624 & .000 & .985 & 1.000 \\
$\quad$ Measurement equivalence & 6.854 & 10 & .739 & .729 & .000 & .985 & 1.000 \\
\hline $\begin{array}{l}\text { Type of production } \\
\quad \text { Configural equivalence }\end{array}$ & 3.533 & 8 & .897 & .914 & .000 & .989 & 1.000 \\
$\quad$ Measurement equivalence & 6.867 & 10 & .738 & .793 & .000 & .984 & 1.000 \\
\hline Type of purchases & & & & & & & \\
$\quad$ Configural equivalence & 5.038 & 8 & .754 & .825 & .000 & .993 & 1.000 \\
$\quad$ Measurement equivalence & 7.157 & 10 & .711 & .801 & .000 & .986 & 1.000 \\
\hline $\begin{array}{l}\text { Product Complexity } \\
\quad \text { Configural equivalence }\end{array}$ & 4.556 & 8 & .803 & .830 & .000 & .990 & 1.000 \\
$\quad$ Measurement equivalence & 5.866 & 10 & .826 & .860 & .000 & .987 & 1.000 \\
\hline $\begin{array}{l}\text { Number of Suppliers } \\
\quad \text { Configural equivalence }\end{array}$ & 9.298 & 8 & .318 & .440 & .018 & .980 & .997 \\
$\quad$ Measurement equivalence & 11.906 & 10 & .991 & .411 & .019 & .974 & .996 \\
\hline Avg. Number of suppliers & & & & & & & \\
$\quad$ Configural equivalence & 10.210 & 8 & .251 & .328 & .025 & .977 & .995 \\
$\quad$ Measurement equivalence & 13.265 & 10 & .209 & .282 & .027 & .970 & .992 \\
\hline
\end{tabular}

Table A. 3 - Standardized measurement weights

\begin{tabular}{lllcc}
\hline Relationship & & & Std. Estimate & P \\
\hline SCMI & $\rightarrow$ & Coordination & .732 & .000 \\
SCMI & $\rightarrow$ & Supply strategy & .693 & - \\
SCMI & $\rightarrow$ & Supplier development & .791 & .000 \\
\hline
\end{tabular}

\section{The IMSS Project}

This project, originally launched by London Business School and Chalmers University of Technology, studies manufacturing strategies within the assembly industry (ISIC 28-35 classification) through a common questionnaire administered simultaneously in many countries by local research groups (Lindberg et al., 1998). The main research goal of the project is to investigate the relationships among strategic priorities, manufacturing practices and improvement programs, manufacturing and business performance, and contingent variables. Companies are usually selected from local databases, and the operations, production or plant manager is contacted as inquire regarding his or her interest in the research. If the respondent agrees, the questionnaire is sent out. When necessary, a reminder is sent after several weeks. Questionnaires that are sent back are controlled for missing data, which are handled case by case, usually by contacting the company once more. Every local research group then controls the gathered data for late respondent bias on company size and industry. Finally, all data are grouped into a unique database, which is further controlled by the project coordinator, and distributed to all partners. For the different editions of the survey, the response has always been higher than $20 \%: 21 \%$ in $1997,33 \%$ in $2001,22 \%$ in 2005 and $18 \%$ in 2009 . The structure of the questionnaire has remained the same over time. The first section of the questionnaire is related to the business unit (gathering general information, such as company size, industry, production network configuration, competitive strategy and business performance), whereas the other sections refer to the plant (focusing on 
manufacturing strategies, practices and performance). Although the structure of the questionnaire has remained the same, with every edition, some questions have been updated or removed, and new questions have been added by the design team, which is composed of a pool of international researchers, to avoid researchers' country biases (Van de Vijver and Leung, 1997).

For further information visit: www.manufacturingstrategy.net

\section{Items of the questionnaire}

SC9. Indicate the effort put into implementing the following action programs in the last three years.

\begin{tabular}{|c|c|c|c|c|c|}
\hline & \multicolumn{5}{|c|}{ Effort in the last three years } \\
\hline & None & & & & High \\
\hline $\begin{array}{l}\text { Rethinking and restructuring supply strategy and the organization and management of supplier } \\
\text { portfolio through e.g. tiered networks, bundled outsourcing, and supply base reduction }\end{array}$ & 1 & 2 & 3 & 4 & 5 \\
\hline Implementing supplier development and vendor rating programs & 1 & 2 & 3 & 4 & 5 \\
\hline $\begin{array}{l}\text { Increasing the level of coordination of planning decisions and flow of goods with suppliers } \\
\text { including dedicated investments (e.g. information systems, dedicated capacity/tools/ equipment, } \\
\text { dedicated workforce) }\end{array}$ & 1 & 2 & 3 & 4 & 5 \\
\hline
\end{tabular}

G1. Where do you source the raw materials, parts/components, subassemblies/systems and manufacture and sell the finished products/services resulting from your plant's dominant activity (answers should add up to 100\%):

\begin{tabular}{|c|c|c|c|}
\hline & Sourcing & Manufacturing $^{1}$ & Sales \\
\hline This country & _ $\%$ & _ $\%$ & _ $\%$ \\
\hline Within your continent & $\%$ & — $\%$ & $\%$ \\
\hline Outside your continent & - $\%$ & $\%$ & $\%$ \\
\hline Total & $100 \%$ & $100 \%$ & $100 \%$ \\
\hline
\end{tabular}

1 In case there are other plants in your company involved in your plant's dominant activity

8 PC3. How many days of production (on average) do you carry in the following inventories: 


\section{Tables}

Table 1 - Contingent variables considered in this study

\begin{tabular}{|c|c|c|c|}
\hline Variable type & Variable & Expected impact & References \\
\hline Product & Product complexity & No impact & $\begin{array}{l}\text { Kotabe and Murray, 2004; } \\
\text { Sharon and Eppinger, } \\
\text { 2001, Perona and } \\
\text { Miragliotta, 204, Westhead } \\
\text { et al., 2001, Chung et al., } \\
2004\end{array}$ \\
\hline Company & Company size & $\begin{array}{l}\text { Positive impact on } \\
\text { the considered } \\
\text { relationships }\end{array}$ & $\begin{array}{l}\text { Cagliano et al., 2008; } \\
\text { Cavusgil, 1980; Lee and } \\
\text { Whang, 2000; Quintens et } \\
\text { al., } 2005\end{array}$ \\
\hline Production & $\begin{array}{l}\text { Decoupling point } \\
\text { position }\end{array}$ & $\begin{array}{l}\text { Make-to-stock and } \\
\text { assemble-to-order } \\
\text { have a positive } \\
\text { impact on the } \\
\text { considered } \\
\text { relationships }\end{array}$ & $\begin{array}{l}\text { Naylor et al., 1999; } \\
\text { Olhager and Östlund, 1990; } \\
\text { Gunasekaran and Ngai, } \\
2005\end{array}$ \\
\hline \multirow{3}{*}{ Purchasing } & $\begin{array}{l}\text { Total number of } \\
\text { suppliers }\end{array}$ & $\begin{array}{l}\text { Negative impact on } \\
\text { the considered } \\
\text { relationships }\end{array}$ & $\begin{array}{l}\text { Choi and Krause, 2006; } \\
\text { Handfield et al., } 2000\end{array}$ \\
\hline & $\begin{array}{l}\text { Average number of } \\
\text { suppliers }\end{array}$ & $\begin{array}{l}\text { Negative impact on } \\
\text { the considered } \\
\text { relationships }\end{array}$ & $\begin{array}{l}\text { Kralijc, 1983; Goffin et al., } \\
\text { 1997; Ogden, } 2006\end{array}$ \\
\hline & $\begin{array}{l}\text { Type of purchased } \\
\text { materials }\end{array}$ & $\begin{array}{l}\text { Purchasing raw } \\
\text { materials has a } \\
\text { negative impact on } \\
\text { the considered } \\
\text { relationships }\end{array}$ & $\begin{array}{l}\text { Cagliano et al. } 2003 \text {, } \\
\text { Gereffi et al., } 2005\end{array}$ \\
\hline
\end{tabular}


Table 2 -Descriptive statistics in terms of (a) country, (b) size, (c) industrial sector (ISIC codes) (a)

\begin{tabular}{lccllcc}
\hline Country & N & \% & Country & N & \% \\
\hline Belgium & 29 & 5.5 & Korea & 21 & 4.0 \\
Brazil & 36 & 6.8 & Mexico & 12 & 2.3 \\
Canada & 14 & 2.6 & The Netherlands & 37 & 7.0 \\
China & 38 & 7.2 & Portugal & 9 & 1.7 \\
Denmark & 13 & 2.4 & Romania & 16 & 3.0 \\
Estonia & 22 & 4.1 & Spain & 33 & 6.2 \\
Germany & 32 & 6.0 & Switzerland & 25 & 4.7 \\
Hungary & 61 & 11.5 & Taiwan & 20 & 3.8 \\
Ireland & 5 & 0.9 & UK & 13 & 2.4 \\
Japan & 16 & 3.0 & USA & 35 & 6.6 \\
\cline { 3 - 5 } Italy & 44 & 8.3 & Total & $\mathbf{5 3 1}$ & $\mathbf{1 0 0 . 0}$
\end{tabular}

* Size: Small: less than 250 employees. Medium: 251-500 employees. Large: over 501 employees

**ISIC Code (Rev. 3.1). 28: Manufacture of fabricated metal products, except

(b) machinery and equipment; 29: Manufacture of machinery and equipment not classified elsewhere; 30: Manufacture of office, accounting and computing machinery; 31 : Manufacture of electrical machinery and apparatus not classified elsewhere; 32: Manufacture of radio, television and communication

\begin{tabular}{l|cc} 
Size $^{*}$ & N & \% \\
\hline Small & 273 & 51.4 \\
Medium & 98 & 18.5 \\
Large & 160 & 30.1 \\
\hline Total & $\mathbf{5 3 1}$ & $\mathbf{1 0 0 . 0}$ \\
\hline
\end{tabular}

\begin{tabular}{c|cc}
\hline \multicolumn{1}{l}{ (c) } & & \\
\hline ISIC** & N & \% \\
\hline 28 & 194 & 36.5 \\
29 & 139 & 26.2 \\
30 & 10 & 1.9 \\
31 & 70 & 13.2 \\
32 & 32 & 6.0 \\
33 & 27 & 5.1 \\
34 & 40 & 7.5 \\
35 & 19 & 3.6 \\
\hline Total & $\mathbf{5 3 1}$ & $\mathbf{1 0 0}$ \\
\hline
\end{tabular}
equipment and apparatus; 33 Manufacture of medical, precision and optical instruments, watches and clocks; 34: Manufacture of motor vehicles, trailers and semi-trailers; 35:Manufacture of other transport equipment.

Table 3 - Descriptive statistics for inventory levels, global sourcing and SCMI

\begin{tabular}{lcccccc}
\hline & Measure & Mean & Median & Std. Deviation & Minimum & Maximum \\
\hline Material inventory level & $\begin{array}{c}\text { n. of days } \\
\text { of } \\
\text { production }\end{array}$ & 27.44 & 15 & 31.46 & 0 & 220 \\
\hline Global sourcing & $\begin{array}{c}\% \\
\text { purchasing } \\
\text { out of } \\
\text { continent }\end{array}$ & 14.50 & 5 & 20.55 & 0 & 100 \\
\hline SCMI* & $\begin{array}{c}1-5 \text { Likert } \\
\text { scale }\end{array}$ & 2.97 & 3 & 0.94 & 1 & 5 \\
\hline
\end{tabular}

* Calculated as the average of: coordination, supplier development, supply strategy 
Table 4 - Groups definitions for the different contingent factors (the number of companies in each group is in brackets)

\begin{tabular}{lcc}
\hline & Group 1 & Group 2 \\
\hline Size & $\begin{array}{c}\text { Number of employees }<250 \\
(256)\end{array}$ & $\begin{array}{c}\text { Number of employees }>=250 \\
(275)\end{array}$ \\
\hline Type of production & $\begin{array}{c}\text { Production mainly based on ETO or } \\
\text { MTO (323) }\end{array}$ & $\begin{array}{c}\text { Production mainly based on ATO or } \\
\text { MTS (178) }\end{array}$ \\
\hline Type of purchases & $\begin{array}{c}\text { Raw materials are more than 50\% of } \\
\text { the total purchases }(274)\end{array}$ & $\begin{array}{c}\text { Parts/components, } \\
\text { subassemblies/systems are more than } \\
50 \% \text { of the total purchases (212) }\end{array}$ \\
\hline Product complexity & $<=3.75(292)$ & $>3.75(237)$ \\
\hline $\begin{array}{l}\text { Total number of } \\
\text { suppliers }\end{array}$ & $<100(219)$ & $>=100(247)$ \\
\hline $\begin{array}{l}\text { Average number of } \\
\text { suppliers per item }\end{array}$ & $<=2(234)$ & $>2(217)$ \\
\hline
\end{tabular}

Table 5 - Model fit statistics for the overall model

\begin{tabular}{lccccccc}
\hline & chi-square & df & p-value & Bollen-Stine p-value & NFI & RMSEA & CFI \\
\hline Default model & 3.666 & 4 & 0.453 & 0.519 & 0.992 & 0.000 & 1.000 \\
\hline NFI: Normed Fit Index (good above 0.95 ) & & & & \\
RMSEA: Root Mean Squared Error of Approximation (good below 0.05) \\
CFI: Comparative fit index: close to 1 means very good fit
\end{tabular}

Table 6 - Structural weights of the overall model (standardised estimates are in brackets) in 2009 and 2005

\begin{tabular}{|c|c|c|c|c|c|c|c|}
\hline & & & \multicolumn{2}{|c|}{2009 Estimate } & \multicolumn{2}{|c|}{2005 Estimates ${ }^{1}$} & \multirow[b]{2}{*}{$\begin{array}{c}\text { Difference } \\
2009-2005 \text { sig. }\end{array}$} \\
\hline \multicolumn{3}{|c|}{ Relationship } & $\begin{array}{c}\text { Estimate } \\
\text { (std. estimate) }\end{array}$ & $\begin{array}{c}\text { Std. } \\
\text { Error }\end{array}$ & $\begin{array}{c}\text { Estimate } \\
\text { (std. estimate) }\end{array}$ & $\begin{array}{c}\text { Std. } \\
\text { Error }\end{array}$ & \\
\hline GS & $\rightarrow$ & MIL & $.166(.108)^{*}$ & .067 & $.111(.094)^{*}$ & .049 & .250 (not sig.) \\
\hline GS & $\rightarrow$ & SCMI & $.005(.145)^{* *}$ & .002 & $.004(.130)^{* *}$ & .001 & .327 (not sig.) \\
\hline SCMI & $\rightarrow$ & MIL & $-6.031(-.148)^{* *}$ & 2.024 & $-7.797(-.200)^{* *}$ & -4.041 & .340 (not sig.) \\
\hline $\begin{array}{l}\text { Numbe } \\
\text { observa }\end{array}$ & $\begin{array}{l}\text { of } \\
\text { ions }\end{array}$ & & 535 & & 540 & & \\
\hline
\end{tabular}


Table 7 - Direct, indirect and total effect of global sourcing on material inventory level in Golini and Kalchschmidt (2011) and this paper

\begin{tabular}{lcc}
\hline & $\begin{array}{c}\text { Standardized Estimate, 2005 } \\
\text { (Golini and Kalchschmidt, 2011) }\end{array}$ & Standardized Estimate, 2009 \\
\hline Direct effect & .094 & .108 \\
Indirect effect & -.026 & -.021 \\
\hline Total effect & $\mathbf{. 0 6 8}$ & $\mathbf{. 0 8 7}$ \\
\hline
\end{tabular}

Table 8 - Average values for different groups for the main model variables (values in bold indicate a significant difference between groups with sig. $<0.05$ as assessed by a Mann-Whitney test).

\begin{tabular}{l|c|c|c|c|c|c|c|c|c|c|c|c}
\hline Variable & \multicolumn{2}{|c|}{ Size } & \multicolumn{2}{c}{$\begin{array}{c}\text { Type of } \\
\text { production }\end{array}$} & \multicolumn{2}{c|}{$\begin{array}{c}\text { Type of } \\
\text { purchases }\end{array}$} & \multicolumn{2}{c|}{$\begin{array}{c}\text { Product } \\
\text { Complexity }\end{array}$} & \multicolumn{2}{c}{$\begin{array}{c}\text { Number of } \\
\text { suppliers }\end{array}$} & \multicolumn{2}{c}{$\begin{array}{c}\text { Avg. } \\
\text { suppliers per } \\
\text { item }\end{array}$} \\
\hline Group & 1 & 2 & 1 & 2 & 1 & 2 & 1 & 2 & 1 & 2 & 1 & 2 \\
\hline MIL & 26.3 & 28.5 & 27.3 & 28.1 & 28.4 & 25.5 & 26.8 & 28.2 & 26.4 & 28.9 & 26.9 & 27.7 \\
\hline GS & $\mathbf{1 0 . 9}$ & $\mathbf{1 7 . 8}$ & $\mathbf{1 1 . 7}$ & $\mathbf{2 0 . 2}$ & $\mathbf{1 3 . 0}$ & $\mathbf{1 7 . 0}$ & $\mathbf{1 2 . 9}$ & $\mathbf{1 6 . 3}$ & $\mathbf{1 2 . 1}$ & $\mathbf{1 5 . 4}$ & $\mathbf{1 5 . 9}$ & $\mathbf{1 2 . 2}$ \\
\hline SCMI & $\mathbf{2 . 8}$ & $\mathbf{3 . 2}$ & $\mathbf{2 . 9}$ & $\mathbf{3 . 1}$ & $\mathbf{2 . 9}$ & $\mathbf{3 . 1}$ & $\mathbf{2 . 8}$ & $\mathbf{3 . 2}$ & $\mathbf{2 . 8}$ & $\mathbf{3 . 1}$ & 2.9 & 3.0 \\
\hline
\end{tabular}

Table 9 - Standardised structural weights for the overall model and the different groups (the regression coefficients with sig. $<=.05$ are highlighted in bold)

\begin{tabular}{llcccccc}
\hline & & \multicolumn{2}{c}{ GS -> MIL } & \multicolumn{2}{c}{ GS -> SCMI } & \multicolumn{2}{c}{ SCMI -> MIL } \\
& & Std. Est & Sig. & Std. Est & Sig. & Std. Est & Sig. \\
\hline Overall model & & .108 & .013 & .145 & .003 & -.148 & .003 \\
\hline \multirow{2}{*}{ Size } & Group 1 & .012 & .842 & .066 & .350 & -.134 & .057 \\
& Group 2 & $\mathbf{. 1 6 9}$ & $\mathbf{. 0 0 5}$ & $\mathbf{. 1 3 7}$ & $\mathbf{. 0 4 6}$ & $\mathbf{- . 1 7 8}$ & $\mathbf{. 0 0 9}$ \\
\hline Type of & Group 1 & .096 & .075 & .062 & .312 & -.081 & .177 \\
production & Group 2 & .138 & .069 & $\mathbf{. 2 5 6}$ & $\mathbf{. 0 0 3}$ & $\mathbf{- . 2 6 7}$ & $\mathbf{. 0 0 3}$ \\
\hline Type of & Group 1 & $\mathbf{. 1 7 3}$ & $\mathbf{. 0 0 4}$ & $\mathbf{. 1 5 5}$ & $\mathbf{. 0 2 1}$ & $\mathbf{- . 1 9 9}$ & $\mathbf{. 0 0 3}$ \\
purchases & Group 2 & .043 & .531 & .074 & .350 & -.061 & .446 \\
\hline Product & Group 1 & $\mathbf{. 1 4 1}$ & $\mathbf{. 0 1 4}$ & .067 & .321 & $\mathbf{- . 2 2 6}$ & $\mathbf{. 0 0 0}$ \\
complexity & Group 2 & .049 & .458 & $\mathbf{. 1 8 4}$ & $\mathbf{. 0 1 1}$ & $\mathbf{- . 0 5 9}$ & .425 \\
\hline Number of & Group 1 & $\mathbf{. 1 6 8}$ & $\mathbf{. 0 1 2}$ & $\mathbf{. 1 6 5}$ & $\mathbf{. 0 2 9}$ & $\mathbf{- . 2 2 6}$ & $\mathbf{. 0 0 3}$ \\
suppliers & Group 2 & .112 & .077 & .044 & .547 & -.102 & .161 \\
\hline Avg. number of & Group 1 & .081 & .224 & $\mathbf{. 1 8 9}$ & $\mathbf{. 0 1 0}$ & $\mathbf{- . 1 6 2}$ & $\mathbf{. 0 3 0}$ \\
suppliers & Group 2 & $\mathbf{. 2 0 2}$ & $\mathbf{. 0 0 2}$ & .022 & .770 & -.146 & .052 \\
\hline
\end{tabular}


Table 10 - Total standardised effect of global sourcing on material inventory levels

\begin{tabular}{llc}
\hline Model & Group & Total effect of GS on MIL \\
\hline Overall model & & .087 \\
\hline \multirow{2}{*}{ Size } & Group 1 & .004 \\
& Group 2 & .145 \\
\hline \multirow{2}{*}{ Type of production } & Group 1 & .091 \\
& Group 2 & .069 \\
\hline \multirow{2}{*}{ Type of purchases } & Group 1 & .142 \\
& Group 2 & .039 \\
\hline \multirow{2}{*}{ Product complexity } & Group 1 & .125 \\
& Group 2 & .038 \\
\hline \multirow{2}{*}{ Number of suppliers } & Group 1 & .131 \\
& Group 2 & .107 \\
\hline \multirow{2}{*}{ Avg. number of suppliers } & Group 1 & .050 \\
& Group 2 & .199 \\
\hline
\end{tabular}


Figure 1 - The relationships among global sourcing, inventories and supply chain management according to Golini and Kalchschmidt (2011)

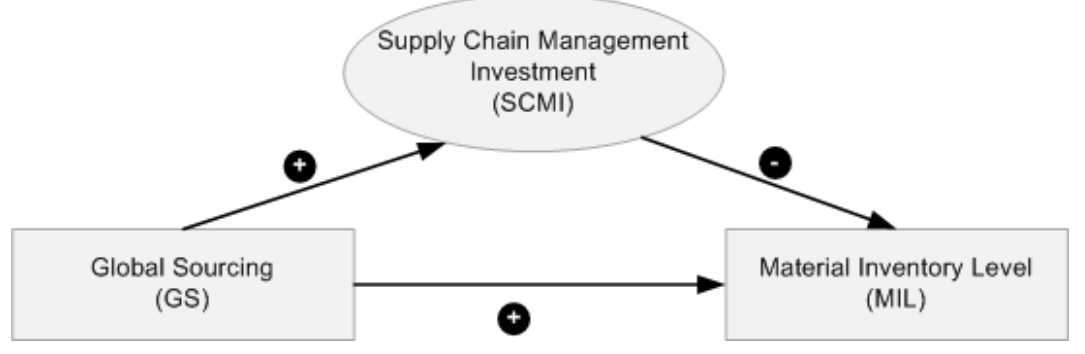

Figure 2 - Structural model. Squares are observed variables, ovals are latent variables. $+/$ - is the expected impact of one variable on the other based on Golini and Kalchschmidt (2011). Thin and dotted arrows represent measurement weights (factors) and bold arrows are structural weights.

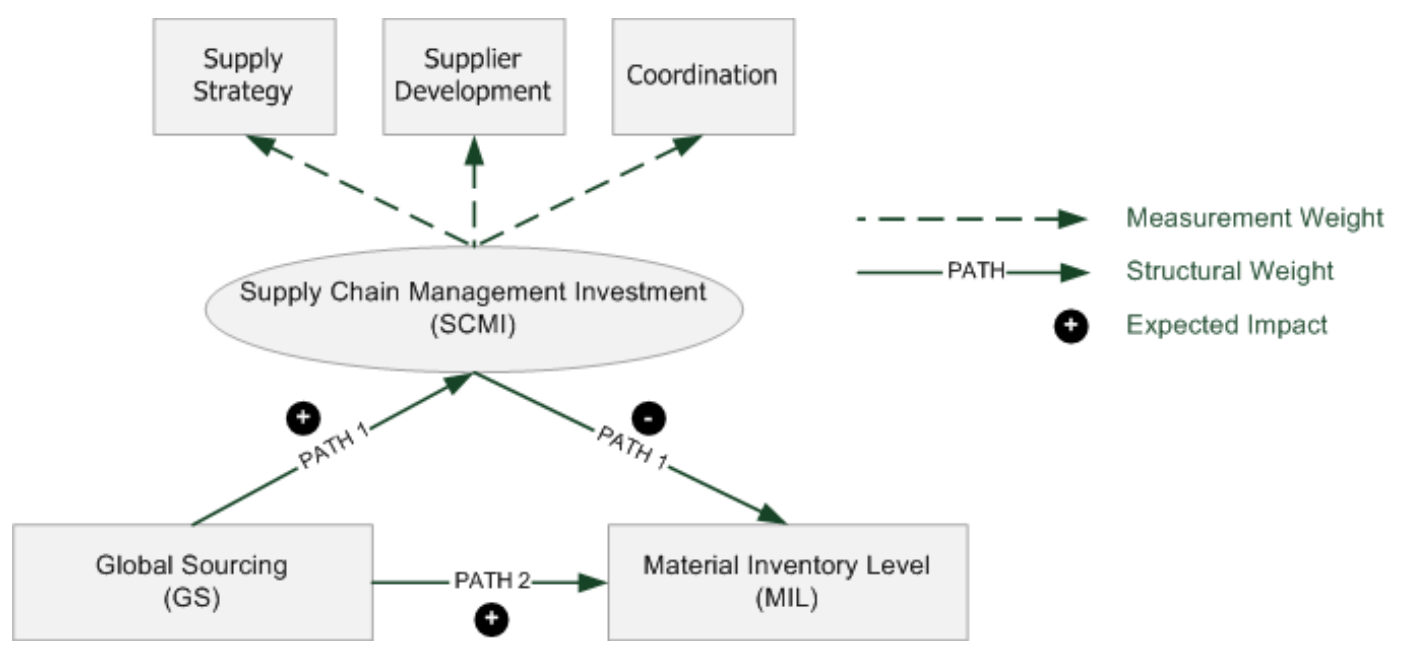

